\title{
Cocaine-induced c-fos Messenger RNA Is Inversely Related to Dynorphin Expression in Striatum
}

\author{
Heinz Steiner and Charles R. Gerfen \\ Section of Neuroanatomy, National Institute of Mental Health, Bethesda, Maryland 20892
}

The effects of the indirect dopamine receptor agonist cocaine in the striatum on levels of mRNAs of the immediateearly gene c-fos and the neuropeptides dynorphin, substance $P$, and enkephalin were analyzed with quantitative in situ hybridization histochemistry. Both single (acute) and repeated (twice a day for 4 d) systemic injections of cocaine (3.75-30 $\mathrm{mg} / \mathrm{kg}$ ) to rats resulted in dose-dependent, regionally specific elevations of mRNA expression in striatal neurons. A single drug treatment elevated c-fos mRNA expression, whereas repeated treatments resulted in little $c$-fos expression but elevated dynorphin mRNA levels. Both the regional and temporal patterns of gene expression revealed an inverse relationship between dynorphin and c-fos expression. This relationship was examined in a time course experiment in which cocaine $(30 \mathrm{mg} / \mathrm{kg})$ was administered for 1, 2, 3 or $4 \mathrm{~d}$. Basal levels of dynorphin expression were relatively high in the ventral striatum, including the nucleus accumbens, a ventrolateral region, and an area along the medial bank of the striatum. A single injection of cocaine induced c-fos mRNA in striatal areas with low basal expression of dynorphin. Thus, $c$-fos mRNA induction was highest in the dorsal central striatum, where basal dynorphin mRNA levels were lowest. In this region, dynorphin mRNA expression increased on subsequent treatment days parallel to diminished c-fos mRNA induction. Changes in substance P mRNA levels appeared to match directly both the temporal and regional patterns of $\mathrm{c}$-fos induction. Enkephalin mRNA expression was altered, but only slightly, by these cocaine treatments.

Statistical analysis of the regional patterns of basal and altered mRNA levels shows a unique inverse relationship between basal dynorphin expression and c-fos induction by cocaine. Further evidence of this relationship is provided by the dose-dependent blockade of cocaine-induced c-fos expression by spiradoline, a dynorphin agonist. Together, these results suggest that the restricted regional pattern of cocaine-induced c-fos expression is related, in part, to the basal level of dynorphin expression, and that cocaine treatment elevates dynorphin expression in striatal regions with

\footnotetext{
Received Feb. 17, 1993; revised June 3, 1993; accepted June 10, 1993.

We thank Jill Marcus and Ron Paletzki for excellent technical assistance. We also thank Tom Engber for discussions of interactions between dopamine and opioid systems. This work was supported in part by a fellowship from the Swiss National Science Foundation (H.S.) and by the Human Frontier Science Project (C.R.G.).

Correspondence should be addressed to Dr. C. R. Gerfen, Section of Neuroanatomy, National Institute of Mental Health, Building 36, Room 2D-10, Bethesda, MD 20892.

Copyright (C 1993 Society for Neuroscience $0270-6474 / 93 / 135066-16 \$ 05.00 / 0$
}

a strong c-fos response, thereby limiting subsequent c-fos induction by cocaine. These findings lead to the hypothesis that dynorphin acts to regulate the responsiveness of striatal neurons to dopamine stimulation.

[Key words: C-fos, dynorphin, substance $P$, enkephalin, cocaine, striatum, dopamine, $\kappa$-receptor]

Experimental manipulations of dopamine neurotransmission alter gene regulation in connectionally and neurochemically defined populations of neurons in the striatum (Gerfen, 1992). The direct action of dopamine has opposite effects on gene regulation in neurons giving rise to the two major striatal output pathways. These neurons - medium spiny neurons, which make up $95 \%$ of the striatal neuron population (Kemp and Powell, 1971) - can be classified into two main subtypes based on their axonal projection targets (Kawaguchi et al., 1990). One subtype, striatopallidal neurons, projects to the globus pallidus. The other subtype, striatonigral neurons, provides a small axon collateral to the globus pallidus, and more extensive axon projections to the entopeduncular nucleus and/or the substantia nigra. Striatopallidal and striatonigral neurons are approximately equal in number and are intermingled throughout the striatum (Beckstead and Kersey, 1985; Gerfen and Young, 1988). Both types of neurons use GABA as their transmitter (Kita and Kitai, 1988), but express different neuropeptides; most striatopallidal neurons express enkephalin, whereas most striatonigral neurons express both dynorphin and substance P (Brownstein et al., 1977; Vincent et al., 1982; Beckstead and Kersey, 1985; Gerfen and Young, 1988). It has been shown that enkephalin mRNA and peptide levels in striatopallidal neurons are elevated by dopamine depletion or by neuroleptic treatment (Hong et al., 1978; Young et al., 1986; Voorn et al., 1987; Gerfen et al., 1990, 1991; Li et al., 1990). In contrast, substance $P$ and dynorphin mRNA and peptide levels in striatonigral neurons are reduced by striatal dopamine depletion and elevated by dopamine agonist treatments (Young et al., 1986; Bannon et al., 1987; Hanson et al., 1987, 1988; Voorn et al., 1987; Li et al., 1988, 1990; Gerfen et al., 1990, 1991). These opposite effects of dopamine manipulations on peptide expression appear to be mediated by the selective expression of the $D_{1}$ and $D_{2}$ dopamine receptor subtypes in striatonigral and striatopallidal neurons, respectively (Gerfen et al., 1990; Le Moine et al., 1990). Thus, in the dopamine-depleted striatum, $\mathrm{D}_{2}$-selective agonist treatment reverses the elevated enkephalin mRNA levels in striatopallidal neurons (Gerfen et al., 1990). Conversely, $D_{1}$-selective agonist treatment elevates peptide mRNA levels specifically in striatonigral neurons (Gerfen et al., 1990). Consistent with these results are studies demonstrating the induction of the immediate-early gene c-fos, which encodes the transcription factor 
Fos, by acute pharmacological treatments. In rats with nigrostriatal lesions, c-fos is induced selectively in striatonigral neurons by a single injection of the $D_{1}$-selective agonist SKF-38393 (Robertson et al., 1990, 1992). Conversely, in unlesioned animals, c-fos is induced selectively in striatopallidal neurons by a single treatment with the $\mathrm{D}_{2}$ antagonist haloperidol (Dragunow et al., 1990; Robertson et al., 1992). Together, these studies suggest that dopamine exerts a direct and opposite effect on gene regulation in striatonigral and striatopallidal neurons through $D_{1}$ and $D_{2}$ receptors, respectively.

Direct effects of dopamine on striatonigral and striatopallidal neurons are demonstrated in studies employing the model of the dopamine-deafferented striatum, where it is possible to analyze effects of activation of one dopamine receptor subtype. Experimental paradigms in which dopamine neurotransmission is altered in the presence of an intact nigrostriatal dopamine system provide additional information that is relevant to the normal functional organization of the striatum. Cocaine, which blocks dopamine reuptake (Heikkila et al., 1975; Taylor and Ho, 1978; Missale et al., 1985) and thereby prolongs its action, alters gene regulation in striatal neurons. Acute cocaine treatment induces c-fos in striatonigral neurons (Cenci et al., 1992), primarily through a $D_{1}$ receptor mechanism (Graybiel et al., 1990; Young et al., 1991). Moreover, repeated treatment with cocaine elevates dynorphin and substance P (Sivam, 1989; Smiley et al., 1990; Hurd et al., 1992) in striatonigral neurons. One striking finding from these studies is the distinct regional pattern in neuronal gene regulation in response to cocaine treatment, with the most pronounced effects occurring in the dorsal striatum (Graybiel et al., 1990; Young et al., 1991). Additionally, whereas the c-fos response has been reported after acute treatment, the elevation of dynorphin has been demonstrated after repeated treatments. In order to analyze possible relationships between cocaine-induced changes in various neuronal gene products, the present study examined regional variations and the time course of changes in the expression of the immediateearly gene $c-f o s$ and the neuropeptides dynorphin, substance $P$, and enkephalin, which serve as markers for the distinct sets of striatal projection neurons.

\section{Materials and Methods}

Subjects and drugs. Male Sprague-Dawley rats (200-300 gm) were used in these experiments. They were housed in groups of five under standard laboratory conditions. In experiments 1 and 2 , rats were injected intraperitoneally with one of the following five doses of cocaine $(n=5$ each): 0 (vehicle), $3.75,7.5,15$, or $30 \mathrm{mg} / \mathrm{kg}$ (cocaine hydrochloride; Sigma; in $0.02 \%$ ascorbic acid, $1 \mathrm{ml} / \mathrm{kg}$ ). Animals in experiment 1 ("acute cocaine") received a single injection. Rats in experiment 2 ("chronic cocaine") were injected twice daily (at 10 A.M. and 5 P.M.) for $3 \mathrm{~d}$ and reccived the final injection (same dose) on day 4 (20-22 hr after the last injection). In experiment 3 ("time course"), rats were injected with cocaine $(30 \mathrm{mg} / \mathrm{kg}$, i.p.) twice daily for $0-3 \mathrm{~d}(n=5 \mathrm{each})$ and received the final injection $(30 \mathrm{mg} / \mathrm{kg}$ ) on drug days 1 (1 d group), 2 ( $2 \mathrm{~d}$ group), 3 ( $3 \mathrm{~d}$ group), or 4 ( $4 \mathrm{~d}$ group). A control group was injected with vehicle ( $0 \mathrm{~d}$ group). The number of injections was equalized with vehicle injections. That is, all groups received a total of seven injections over 4 d. In experiment 4 ("dynorphin agonist"), rats received one of five doses of the $\kappa$-receptor agonist spiradoline [U-62066, Research Biochemicals; 0 (vehicle), $0.5,1,5,10 \mathrm{mg} / \mathrm{kg}$, i.p.; $n=4$ or 5$] 15 \mathrm{~min}$ prior to a single injection of $30 \mathrm{mg} / \mathrm{kg}$ cocaine. These animals had been habituated to the injection procedure by administration of six vehicle injections over the $2 \mathrm{~d}$ preceding the experiment. In all of these experiments, drug effects on behavior were assessed by observing the animals in their home cage.

Tissue section preparation. All rats were decapitated $30 \mathrm{~min}$ after the last injection. The brains were quickly removed, frozen for $15 \mathrm{sec}$ in isopentane cooled on dry ice, and stored at $-30^{\circ} \mathrm{C}$ until cryostat sectioning. Coronal sections $(12 \mu \mathrm{m})$ were adhered to glass slides twice coated with gelatin, and then dried to the slide on a warm plate and stored at $-20^{\circ} \mathrm{C}$. For further processing, the slides were first warmed to room temperature, and then fixed in a $4 \%$ paraformaldehyde solution (in $0.9 \%$ saline) for $10 \mathrm{~min}$ and incubated in a fresh solution of $0.25 \%$ acetic anhydride in $0.1 \mathrm{~m}$ triethanolamine and $0.9 \%$ saline $(\mathrm{pH} 8.0)$ for $10 \mathrm{~min}$. The slide-mounted sections were then dehydrated in a series of ascending concentrations of ethanol, defatted for $2 \times 5 \mathrm{~min}$ in chloroform, rehydrated, and air dried. The sections were stored at $-80^{\circ} \mathrm{C}$ until hybridization.

Oligonucleotide probes. Tails of ${ }^{35} \mathrm{~S}$-dAMP (average tail length, 20 bases) were added to purified oligonucleotides (48-base cDNAs) complementary to the mRNAs for c-fos (experiments 1-4), dynorphin (experiments 1-3), substance $P$ and enkephalin (experiment 3) (Young et al., 1986) in the following reaction: $1 \mu \mathrm{l}$ of each probe (from a stock concentration of $5 \mu \mathrm{M}$ ) was reacted with ${ }^{35} \mathrm{~S}$-dATP (final concentration equal to $1 \mu \mathrm{M}$ of $\left.1350 \mathrm{Ci} / \mathrm{mmol}^{35} \mathrm{~S}-\mathrm{dATP}\right)$ and $80 \mathrm{U} / 4 \mu \mathrm{l}$ of terminal deoxynucleotidyl transferase (TdT; Boehringer Mannheim, Indianapolis, IN) for $5 \mathrm{~min}$ at $37^{\circ} \mathrm{C}$. The reaction was terminated with the addition of $1 \mu \mathrm{l}$ of tRNA $(25 \mu \mathrm{g} / \mu \mathrm{l})$ and $450 \mu \mathrm{l}$ of $10 \mathrm{~mm}$ Tris $\mathrm{HCl}(\mathrm{pH}$ 7.5)/EDTA (TE), and the labeled probe was extracted with phenol/ chloroform/isoamyl alcohol followed by chloroform/isoamyl alcohol. To the extracted aqueous phase was added $1 / 20 \mathrm{vol}$ of $4 \mathrm{M} \mathrm{NaCl}$ and $1 \mathrm{ml}$ of ethanol, which was allowed to cool on dry ice for $20 \mathrm{~min}$. The precipitate was pelleted at $14000 \mathrm{rpm}$ for $12 \mathrm{~min}$, washed with ice-cold ethanol, and resuspended in $50 \mu \mathrm{l}$ of TE.

Hybridization. Labeled probes were added to hybridization buffer (Young et al., 1986) to reach a concentration of $0.4-1 \times 10^{6} \mathrm{dpm}$ per $25 \mu \mathrm{l}$ of buffer. Twenty-five microliters of hybridization buffer containing labeled probe were added to each brain section. The sections were coverslipped with parafilm and incubated overnight at $37^{\circ} \mathrm{C}$. After incubation, the coverslips were floated off in $1 \times$ saline-sodium citrate (SSC) ( $1 \times$ SSC contains $150 \mathrm{~mm}$ sodium chloride and $15 \mathrm{~mm}$ sodium citrate), and the slide-mounted sections were rinsed in four washes of $1 \times$ SSC. The slides were then washed $4 \times 15 \mathrm{~min}$ in $2 \times \mathrm{SSC} / 50 \%$ formamide at $41^{\circ} \mathrm{C}$, followed by $2 \times 30$ min washes in $1 \times \mathrm{SSC}$ at room temperature and a brief water rinse, before the sections were air dried. The slides were then apposed to x-ray film (X-Omat, Kodak) for 2-5 weeks. After the films were developed, the slides were dipped in NTB3 autoradiography emulsion (Kodak) (diluted 1:1 with water containing $0.1 \%$ Dreft) and exposed for 8-12 wecks. Aftcr devcloping, they were counterstained with thionin, dehydrated, and coverslipped out of xylene.

Analysis of autoradiograms. Sections from four rostrocaudal levels were examined (Fig. 1): a frontal (about at $11.5 \mathrm{~mm}$ rostral to the interaural line; Paxinos and Watson, 1982), a rostral striatal (10.5 mm), a mid-striatal $(9.5 \mathrm{~mm})$, and a caudal striatal level $(8.0 \mathrm{~mm})$. In experiments 1 and 2, striatal mRNA levels were assessed in dorsomedial, dorsolateral, ventrolateral, and ventromedial quadrants or ventral parts (Fig. $1 B-D$, left side). These arbitrary regions were sufficient for the purpose of these experiments, in which parameters of drug dose and delivery were determined. However, for the more detailed analysis performed in experiment 3 , the striatum was subdivided on the basis of its more complex regional heterogeneity. Thus, the following striatal areas were chosen (Fig. $1 B-D$, right side): a dorsomedial periventricular zone with high basal dynorphin expression; a dorsal central zonc, which shows maximal c-fos induction by cocaine; an area with high basal expression of substance $P$, situated dorsolaterally on the rostral striatal section, laterally at the middle, and more ventrolaterally at the caudal striatal level; and a ventrolateral or ventral area also rich in basal dynorphin mRNA. Additionally, the nucleus accumbens was dissected into a core and a shell region (Zaborszky et al., 1985), based on differential basal expression of substance $P$ in these regions. In the first three experiments, c-fos expression was also analyzed in the claustrum and the medial frontal cortex (frontal level), and in the cingulate cortex (rostral through caudal striatal levels) (Fig. 1). In experiment 4, c-fos expression was assessed in the dorsal central region of the striatum and in the cingulate cortex, at rostral, middle, and caudal levels.

Labeling was measured from film with a Macintosh-based image analysis system (IMAGE, Wayne Rasband, NIMH). For each rcgion, mcan optical density (OD) values were assessed in both hemispheres and averaged. OD values given are corrected for background by subtraction of the OD value of the corpus callusum. For the analysis of regional differences in changes in neuropeptide expression (experiment 3 ), the maximal increase in mRNA levels (peak induction) was determined as 

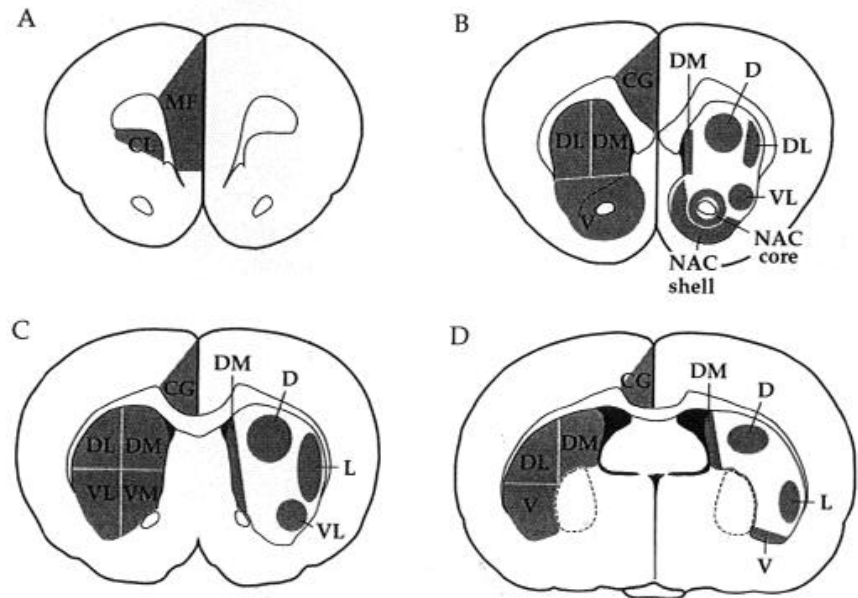

Figure 1. Schematic representation of the forebrain areas in which changes in gene expression were analyzed. OD values were measured in regions at a frontal $(A)$, rostral $(B)$, middle $(C)$, and caudal striatal $(D)$ level. The regions examined in the dose-response experiments (experiments 1 and 2) are shown on the left side of each diagram: dorsomedial $(D M)$, dorsolateral $(D L)$, ventrolateral $(V L)$, and ventromedial $(V M)$ quadrants and ventral $(V)$ parts of the striatum, and medial frontal cortex $(M F)$, claustrum $(C L)$, and cingulate cortex $(C G)$. The striatal regions depicted on the right side of the diagrams were designed for the time course experiment (experiment 3): dorsomedial $(D M)$, ventrolateral $(V L)$ and ventral $(V)$ areas with high basal dynorphin expression, dorsal $(D)$ central areas with high c-fos induction by cocaine, dorsolateral $(D L)$ and lateral $(L)$ regions with high basal substance $\mathrm{P}$ expression, and nucleus accumbens $(N A C)$ core and shell regions. follows: for dynorphin and enkephalin, signal in the $2 \mathrm{~d}$ group divided by signal in the $0 \mathrm{~d}$ group; for substance $\mathrm{P}$, signal in the $1 \mathrm{~d}$ group divided by that in the $0 \mathrm{~d}$ group; for $\mathrm{c}$-fos, signal in the $1 \mathrm{~d}$ group minus that in the $0 \mathrm{~d}$ group (this measure was chosen for c-fos due to the very low basal levels of this mRNA).

Statistics. Drug effects were determined with one-factor analysis of variance (ANOVA). In experiments 1, 2, and 4, Dunnett's test was used post hoc to assess the effects of individual doses of cocaine, or spiradoline, compared to vehicle, or cocaine controls, respectively. In experiment 3, the Tukey-Kramer test was applied to compare the different groups. In addition, the expression (basal expression and peak induction) of the four mRNAs in the 14 striatal regions was compared by a correlation analysis (Pearson's correlation). All $p$ values presented are two tailed.

\section{Results}

\section{Experiment 1: acute cocaine}

Behavior. Vehicle-injected rats did not exhibit much activity, but spent most of the postinjection period piled up in a corner of the cage. After the injection of the two lower doses of cocaine $(3.75$ and $7.5 \mathrm{mg} / \mathrm{kg})$, rats were more activated, showing repetitive sniffing, rearing, and some locomotor activity for several minutes. The higher doses (15 and $30 \mathrm{mg} / \mathrm{kg}$ ) produced more intense repetitive behavior, including sniffing, rearing, locomotion, and some side-to-side head movements (head bobbing). These two doses mainly differed in the duration of activation. Whereas rats that received $15 \mathrm{mg} / \mathrm{kg}$ were relatively inactive by the time of decapitation (30 min after the injection), those injected with the highest dose were still activated.

$c$-fos $m R N A$ expression. Acute injection of cocaine resulted in a dose-dependent induction of c-fos mRNA in striatal neu-

Table 1. Expression of c-fos and dynorphin mRNA in striatal regions following a single (acute) or repeated (chronic) administration of various doses of cocaine

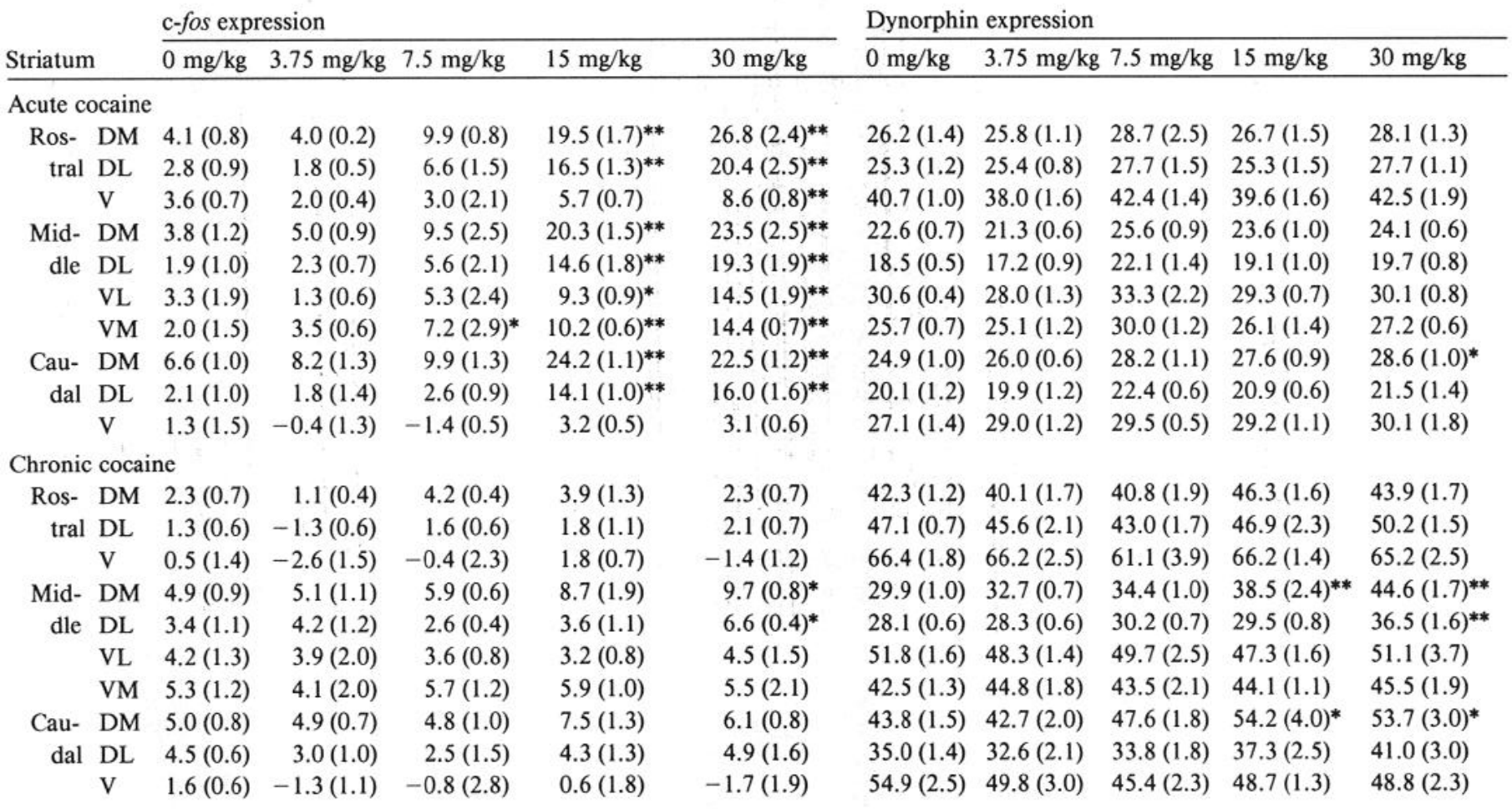

Animals were killed 30 min after the single injection, or 30 min after the last injection of the 4 d chronic treatment. Data represent mean (SEM) OD values measured

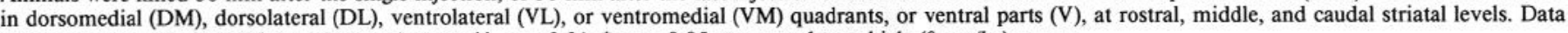
were analyzed with ANOVA and Dunnett's tests: ${ }^{* *}, p<0.01 ;{ }^{*}, p<0.05$; compared to vehicle $(0 \mathrm{mg} / \mathrm{kg}) \mathrm{groups}$. 


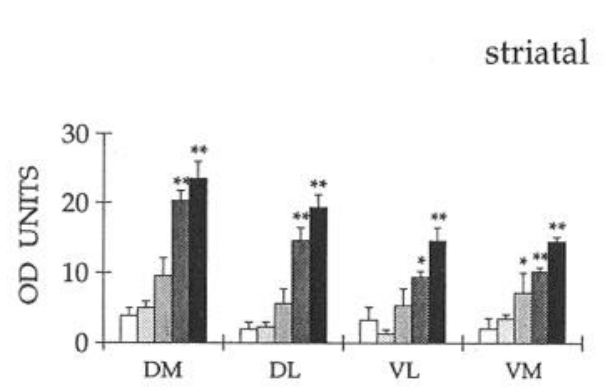

striatal dynorphin expression

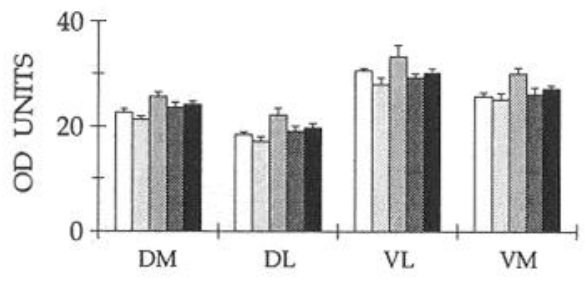

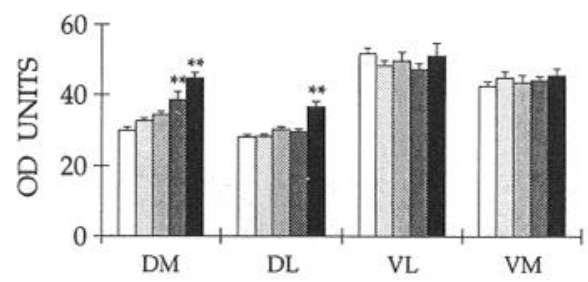

Figure 2. Dose-dependent changes in striatal c-fos and dynorphin mRNA expression following acute and chronic cocaine treatments. OD values (mean + SEM) in dorsomedial $(D M)$, dorsolateral $(D L)$, ventrolateral $(V L)$, and ventromedial $(V M)$ quadrants at the middle striatal level are given for animals killed $30 \mathrm{~min}$ after the single injection (acute cocaine, left), or $30 \mathrm{~min}$ after the last injection of the $4 \mathrm{~d}$ repeated treatment (chronic cocaine, right) with $0-30 \mathrm{mg} / \mathrm{kg}$ of cocaine. Acute cocaine produces a dose-dependent increase in c-fos expression (top), whereas the c-fos response is much reduced or absent following the chronic treatment. In contrast to $c-f o s$ expression, repeated cocaine treatment results in a dose-dependent increase in dynorphin expression (bottom) in areas that show a relatively low basal expression of dynorphin and a strong c-fos response to acute cocaine. ${ }^{* *}, p<0.01 ; *, p<$ 0.05 ; compared to vehicle $(0 \mathrm{mg} / \mathrm{kg})$ groups (ANOVA, Dunnett's test). rons, with distinct regional variations in amount (Table 1, Fig. 2). The two higher ( 15 and $30 \mathrm{mg} / \mathrm{kg}$ ), but not the two lower, doses produced a significant increase in c-fos labeling (compared to vehicle controls) in dorsomedial and dorsolateral quadrants at all three striatal levels. In contrast, in ventral striatal parts, the c-fos response was generally weaker and less uniform. No influence of cocaine on c-fos expression was seen in the cortical areas examined (Fig. 3).

Dynorphin $m R N A$ expression. Thirty minutes after the acute cocaine injection, there was minimal influence on striatal dynorphin expression (Table 1, Fig. 2).

\section{Experiment 2: chronic cocaine}

Behavior. After the first drug injection, the rats displayed behavioral patterns similar to those described above. The lower doses induced some sniffing and rearing, with little locomotion, for 5-15 min. The higher doses produced, in addition to more intense sniffing and rearing, more locomotor activity and some head bobbing. Repeated cocaine administration seemed to produce more activation. However, especially with $30 \mathrm{mg} / \mathrm{kg}$, a shift in behavioral patterns was observed, rather than simply an increase in intensity or duration. For example, such rats exhibited more intense head bobbing, sometimes accompanied by highly repetitive scanning of restricted parts of the wall. In such situations, locomotion decreased considerably.

$c$-fos $m R N A$ expression. In contrast to the effects seen after a single cocaine injection, repeated cocaine treatment did not produce a comparable c-fos response in any of the striatal regions (Table 1, Fig. 2). Only in the dorsal quadrants of the middle striatum after a $30 \mathrm{mg} / \mathrm{kg}$ injection was there an increase in c-fos

\section{cortical c-fos expression}
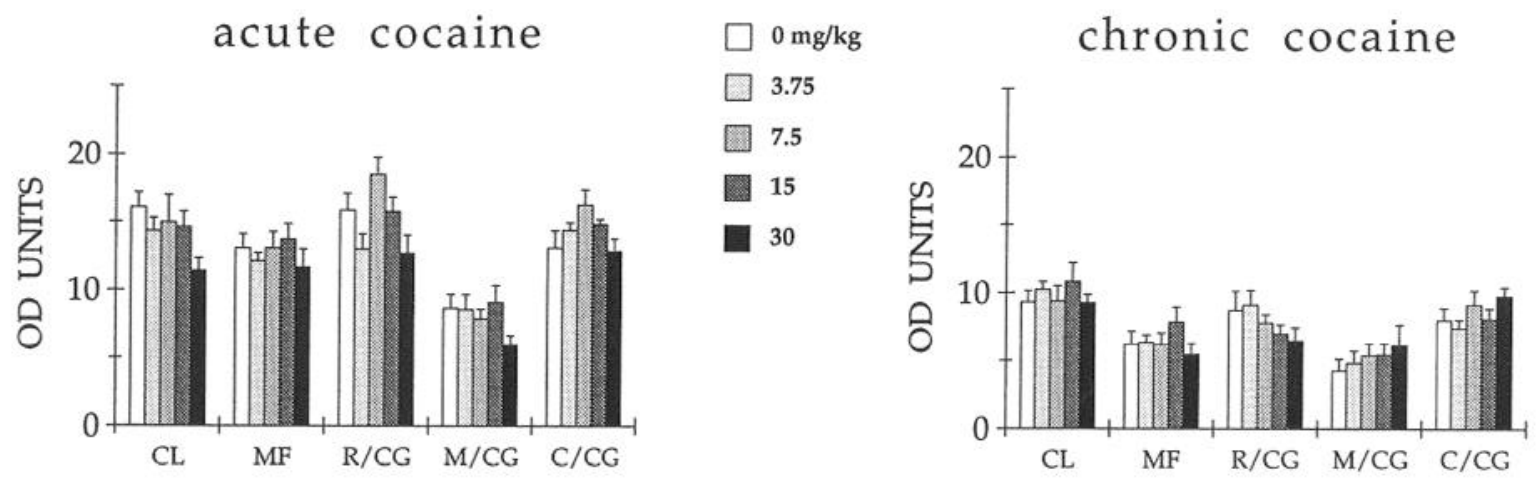

Figure 3. Influence of acute and chronic cocaine treatments on c-fos expression in cortical areas. OD values (mean + SEM) in claustrum (CL), medial frontal cortex $(M F)$, and cingulate cortex at rostral $(R / C G)$, middle $(M / C G)$, and caudal $(C / C G)$ striatal levels are depicted for animals killed $30 \mathrm{~min}$ after the single injection (acute cocaine, left), or $30 \mathrm{~min}$ after the last injection of the $4 \mathrm{~d}$ repeated treatment (chronic cocaine, right) with $0-30 \mathrm{mg} / \mathrm{kg}$ of cocaine. No statistically significant effects of either treatment are seen in these cortical areas. 
labeling. Also, repeated cocaine did not induce changes in c-fos expression in cortical areas (Fig. 3). However, in these cortical regions, the basal levels of $\mathrm{c}-$ fos expression $(0 \mathrm{mg} / \mathrm{kg})$ appeared to be lower after repeated injections than in the acute experiment, while basal levels in striatum were similar in these two conditions. There are several possible reasons for this difference, some of which may be related to differences in the handling procedures.

The exception was a rat from the $15 \mathrm{mg} / \mathrm{kg}$ group that developed seizures after the last cocaine injection, and whose data were excluded from the statistical analysis. This rat showed an increased c-fos signal in many brain areas, including the cortical areas examined and all parts of the striatum. Under these conditions, the c-fos value in, for example, the rostral ventral part was about 20-30 times higher than that in similarly treated animals without seizures or in vehicle controls.

Dynorphin $m R N A$ expression. Repeated cocaine treatment affected dynorphin expression in dorsal parts of the striatum at middle and caudal levels (Table 1, Fig. 2). In the dorsomedial quadrant of the middle striatal level, injections of both 15 and $30 \mathrm{mg} / \mathrm{kg}$ cocaine increased the dynorphin signal, whereas in the dorsolateral quadrant only the latter dose did. A drug effect was also seen in the dorsomedial part at the caudal level, with both higher doses increasing dynorphin labeling. The striatal dynorphin mRNA levels of the rat that developed seizures were in the range of the values of the other animals in that group.

\section{Experiment 3: time course}

Behavior. The final cocaine injection induced the most locomotor activity in $2 \mathrm{~d}$ rats. Three rats of the $1 \mathrm{~d}$ group were activated by the drug, but to a lesser degree, showing sniffing, rearing, and some locomotion. Two animals of this group were not activated by the injection and were excluded from the study, based on our experience that rats lacking a behavioral response to such cocaine doses fail to show effects on gene regulation. Rats of the 3 and $4 \mathrm{~d}$ groups, in contrast, exhibited less locomotor activity than the $2 \mathrm{~d}$ group, but more intense head bobbing, in addition to sniffing and rearing. Some of these animals stayed for longer periods in a given sector of the cage, showing only sniffing and the highly repetitive side-to-side head movements. The $0 \mathrm{~d}$ group, by comparison, spent most of the survival period relatively inactive in a corner of the cage.

Basal expression of striatal $c$-fos, dynorphin, substance $P$, and enkephalin $m R N A$. In contrast to the first two experiments in which the striatum was divided into quadrants, in experiment 3 mRNA levels were examined in regions defined on the basis of basal dynorphin and substance $P$ expression, as well as $c-f o s$ induction by cocaine. Regional differences in basal expression of the four mRNAs in the $0 \mathrm{~d}$ group are reported in Tables 2 and 3. At all three striatal levels, basal c-fos expression was generally very low and did not differ between the regions examined. Dynorphin was expressed in all striatal regions, but mRNA levels varied considerably between areas (Table 3; Figs. $4 A, 5$ ). The area with the highest level of basal dynorphin expression was the ventrolateral region throughout the rostrocaudal extent of the striatum (Table 3). The nucleus accumbens displayed the next highest level, with no difference between core and shell regions (Fig. 6), followed by the dorsomedial zone bordering the lateral ventricle. The areas with the lowest levels of basal dynorphin expression were the dorsal central and lateral regions. In these areas, patches displayed greater dynorphin expression than matrix (Gerfen et al., 1991) (see Fig. 4A). Basal substance $\mathrm{P}$ expression displayed a distinct medial-to-lateral gradient, with highest expression laterally (Table 3, Fig. 7A). Along the rostral-to-caudal axis, the center of highest labeling shifted from dorsolateral (rostral level) to more ventrolateral. Comparing levels of dynorphin and substance $P$ expression shows that in most sections the zones with the highest substance $P$ mRNA levels displayed the lowest dynorphin mRNA levels, and vice versa. The nucleus accumbens displayed varying levels of substance P mRNA in shell and core (Fig. 6). Striatal enkephalin expression was, overall, more evenly distributed than the expression of the other neuropeptides (Table 2). However, there was more enkephalin expression in the ventrolateral region, which also contained the highest dynorphin $\mathrm{mRNA}$ levels.

Cocaine-induced $c$-fos $m R N A$ expression. Similar to the results of the acute experiment, c-fos mRNA induction in the 1 $\mathrm{d}$ group was greatest in dorsal central and dorsolateral regions (Table 2, Figs. $4 C, 5,6,8$ ). The 2 d group showed an increase similar to that of the $1 \mathrm{~d}$ group. In contrast, in the 3 and $4 \mathrm{~d}$ groups, c-fos expression was not or only minimally enhanced over that of vehicle controls. Statistical analysis of regional differences in the maximal induction of c-fos expression by cocaine shows that c-fos induction was significantly higher in the dorsal central zone than in all other zones, at all three striatal levels (Table 3). Rostrally, the increase in c-fos labeling was also significantly higher in the dorsolateral, substance $\mathrm{P}$ mRNA-rich area than in the medial or ventral areas, and higher in the ventrolateral zone than in the nucleus accumbens regions.

Cocaine-induced dynorphin $m R N A$ expression. The influence of cocaine treatment on striatal dynorphin expression was strongest in dorsal central and dorsolateral parts at all three striatal levels (Table 2, Figs. $4 B, 6,8$ ). The increase in dynorphin labeling was maximal in the $2 \mathrm{~d}$ group, and could also be secn in both the 3 and $4 \mathrm{~d}$ groups, but was absent in the $1 \mathrm{~d}$ group. In almost all regions affected by the treatment, dynorphin mRNA levels were significantly higher in the $2 \mathrm{~d}$ group than after the first drug treatment. The regional analysis confirms that the peak induction of dynorphin during chronic cocaine treatment was significantly greater in dorsal central and dorsolateral areas than in the other striatal areas examined (Table 3 ).

Cocaine-induced substance $P m R N A$ expression. Cocaine affected the levels of substance $P$ mRNA in dorsal and lateral parts of the striatum (Table 2, Figs. 6, 7B, 8). In contrast to dynorphin, the time course of changes in substance $P$ expression matched that of changes in c-fos expression. That is, the increase in substance $\mathbf{P}$ expression also peaked on drug day 1 and was reduced thereafter, resulting in no or only a slight increase on days 3 and 4 . The regional analysis of peak induction showed significantly greater substance $P$ responses in dorsal central and dorsomedial zones than in ventral parts, especially at mid- and caudal striatal levels (Table 3 ).

Cocaine-induced enkephalin $m R N A$ expression. Changes in striatal enkephalin mRNA levels due to chronic cocaine treatment followed, overall, a time course similar to that of dynorphin expression, with increased enkephalin labeling in 2 and 3 $\mathrm{d}$ groups, again mainly in dorsal central and dorsolateral parts of the striatum (Table 2, Figs. 6, 8). However, these changes were of a smaller magnitude than those in expression of the other neuropeptides.

Regional correlations between the expression of $c$-fos, dynorphin, substance $P$, and enkephalin. Basal expression and peak induction by cocaine of these mRNAs in different striatal areas were also compared with correlation analysis (Table 4, Fig. 9). 
Table 2. Expression of c-fos, dynorphin (DYN), substance P (SP) and enkephalin (ENK) mRNA in striatal regions during chronic cocaine treatment

\begin{tabular}{|c|c|c|c|c|c|c|}
\hline & & $0 \mathrm{~d}$ & $1 \mathrm{~d}$ & $2 d$ & $3 \mathrm{~d}$ & $4 d$ \\
\hline \multicolumn{7}{|l|}{ c-fos } \\
\hline \multirow[t]{4}{*}{ Rostral } & DM & $9.7(1.1)$ & $16.8(1.5)$ & $15.9(2.3)$ & $9.3(0.9)^{2}$ & $9.7(1.4)$ \\
\hline & D & $9.4(0.7)$ & $51.9(1.8)^{* * *}$ & $40.5(4.9)^{* *}$ & $13.4(0.7)^{22}$ & $14.4(1.8)$ \\
\hline & DL & $7.2(0.3)$ & $29.6(2.0)^{* *}$ & $30.2(3.3)^{* *}$ & $8.4(0.8)^{22}$ & $9.6(0.5)$ \\
\hline & VL & $9.1(1.0)$ & $19.7(1.1)^{* *}$ & $17.2(1.1)^{* *}$ & $10.6(1.3)^{22}$ & $10.3(0.8)$ \\
\hline \multirow[t]{4}{*}{ Middle } & DM & $8.9(0.8)$ & $20.0(2.4)^{* *}$ & $15.0(1.9)^{*}$ & $10.8(0.8)^{11}$ & $11.1(0.9)$ \\
\hline & D & $6.8(1.3)$ & $49.7(0.5)^{* *}$ & $47.4(2.3)^{* *}$ & $19.9(1.4)^{* *, 22}$ & $16.7(3.7)^{*}$ \\
\hline & $\mathbf{L}$ & $6.6(1.2)$ & $20.0(2.2)^{* *}$ & $24.6(1.4)^{* *}$ & $6.6(0.6)^{22}$ & $6.6(1.3)$ \\
\hline & VL & $7.5(0.7)$ & $18.0(2.2)^{* *}$ & $11.5(1.1)^{1}$ & $9.2(1.3)^{11}$ & $6.8(0.9)$ \\
\hline \multirow[t]{4}{*}{ Caudal } & DM & $5.9(1.1)$ & $22.9(4.3)^{* *}$ & $17.6(1.6)^{* * *}$ & $10.5(1.5)^{11}$ & $12.7(1.3)$ \\
\hline & D & $7.4(1.5)$ & $57.5(2.3)^{* *}$ & $53.3(4.3)^{* * *}$ & $18.8(1.8)^{22}$ & $24.1(4.0)^{* *}$ \\
\hline & $\mathbf{L}$ & $4.2(0.9)$ & $19.6(2.4)^{* *}$ & $21.1(2.5)^{* *}$ & $5.5(1.2)^{22}$ & $5.6(1.1)$ \\
\hline & V & $5.1(0.9)$ & $6.3(1.8)$ & $6.6(1.2)$ & $5.4(1.2)$ & $6.8(0.5)$ \\
\hline \multicolumn{7}{|l|}{$\mathbf{S P}$} \\
\hline \multirow[t]{4}{*}{ Rostral } & DM & $39.6(2.5)$ & $51.7(3.5)^{*}$ & $52.9(2.4)^{* *}$ & $50.1(2.4)^{*}$ & $45.9(2.1)$ \\
\hline & $\mathrm{D}$ & $65.2(4.0)$ & $112.8(7.2)^{* *}$ & $98.6(4.8)^{* *}$ & $77.2(2.2)^{11,2}$ & $80.2(5.1)$ \\
\hline & $\mathrm{DL}$ & $83.7(3.2)$ & $119.0(9.0)^{* *}$ & $110.8(9.3)^{*}$ & $85.0(3.2)^{2}$ & $94.9(3.1)$ \\
\hline & VL & $58.2(6.1)$ & $74.8(7.3)$ & $68.3(4.0)$ & $60.6(2.8)$ & $58.3(5.6)$ \\
\hline \multirow[t]{4}{*}{ Middle } & DM & $26.3(1.9)$ & $49.6(1.1)^{* * *}$ & $37.2(1.5)^{*, 1}$ & $37.2(3.6)^{*}$ & $40.4(2.4)^{* *}$ \\
\hline & D & $58.7(1.1)$ & $109.0(2.8)^{* * *}$ & $92.2(5.5)^{* *}$ & $70.7(3.3)^{11,2}$ & $74.0(9.2)$ \\
\hline & $\mathbf{L}$ & $86.1(3.8)$ & $120.2(2.8)^{* *}$ & $115.5(5.6)^{* *}$ & $92.9(2.4)^{2}$ & $99.5(7.0)$ \\
\hline & VL & $38.9(2.2)$ & $37.5(2.5)$ & $41.0(2.4)$ & $43.5(1.9)$ & $39.2(5.5)$ \\
\hline \multirow[t]{4}{*}{ Caudal } & DM & $23.7(3.3)$ & $40.9(2.7)^{* *}$ & $27.4(2.2)^{1}$ & $25.8(3.2)$ & $33.2(2.0)$ \\
\hline & $\mathrm{D}$ & $40.8(2.4)$ & $93.7(8.1)^{* * *}$ & $74.1(7.0)^{* *}$ & $58.1(4.9)^{11}$ & $66.3(5.9)^{*}$ \\
\hline & $\mathrm{L}$ & $78.0(4.9)$ & $114.8(9.9)$ & $102.5(12.5)$ & $80.8(4.5)$ & $101.4(7.4)$ \\
\hline & V & $44.1(2.0)$ & $29.5(3.4)$ & $46.4(4.3)$ & $50.8(1.7)^{1}$ & $44.7(5.9)$ \\
\hline \multicolumn{7}{|l|}{ DYN } \\
\hline \multirow[t]{4}{*}{ Rostral } & DM & $51.2(3.6)$ & $57.8(1.4)$ & $57.6(1.9)$ & $54.8(0.9)$ & $57.0(1.7)$ \\
\hline & $\mathrm{D}$ & $41.2(1.6)$ & $45.3(0.7)$ & $63.3(4.3)^{* *, 11}$ & $54.9(2.8)^{*}$ & $53.1(1.3)^{*}$ \\
\hline & $\mathrm{DL}$ & $40.9(1.7)$ & $45.5(2.0)$ & $64.2(4.6)^{* *, 11}$ & $57.1(1.9)^{* *}$ & $54.8(2.5)^{*}$ \\
\hline & VL & $78.1(2.3)$ & $78.1(0.3)$ & $88.8(2.1)$ & $86.3(3.3)$ & $85.2(3.4)$ \\
\hline \multirow[t]{4}{*}{ Middle } & $\mathrm{DM}$ & $51.2(1.9)$ & $57.3(2.9)$ & $59.1(2.2)$ & $58.4(1.5)$ & $60.7(3.1)$ \\
\hline & $\mathrm{D}$ & $28.9(0.9)$ & $28.5(0.4)$ & $50.5(5.9)^{* *, 11}$ & $47.4(3.4)^{* *}$ & $43.2(1.3)^{*}$ \\
\hline & L & $34.5(1.6)$ & $34.4(0.5)$ & $50.9(5.4)^{* *, 1}$ & $44.1(2.6)$ & $43.5(1.6)$ \\
\hline & VL & $65.8(2.7)$ & $62.5(2.2)$ & $75.1(2.9)$ & $69.5(3.0)$ & $68.8(3.1)$ \\
\hline \multirow[t]{4}{*}{ Caudal } & $\mathrm{DM}$ & $61.5(2.1)$ & $74.2(4.8)$ & $77.7(2.9)^{* *}$ & $75.9(1.7)^{*}$ & $72.3(3.3)$ \\
\hline & D & $33.7(1.6)$ & $37.7(0.5)$ & $68.8(7.4)^{* *, 11}$ & $67.9(2.2)^{* *}$ & $57.9(3.2)^{* *}$ \\
\hline & $\mathbf{L}$ & $40.2(1.9)$ & $42.1(4.4)$ & $52.1(3.0)$ & $44.7(3.1)$ & $43.9(2.0)$ \\
\hline & $\mathbf{V}$ & $91.7(3.5)$ & $93.3(4.4)$ & $107.7(3.2)^{* * .1}$ & $99.9(2.0)$ & $88.5(1.6)^{22}$ \\
\hline \multicolumn{7}{|l|}{ ENK } \\
\hline \multirow[t]{4}{*}{ Rostral } & DM & $24.2(2.2)$ & $29.4(1.8)$ & $26.3(1.5)$ & $25.6(1.0)$ & $25.4(0.7)$ \\
\hline & D & $38.3(2.1)$ & $45.9(0.8)$ & $49.1(1.7)^{* *}$ & $49.3(1.8)^{* *}$ & $42.3(1.3)$ \\
\hline & DL & $35.2(2.9)$ & $38.1(2.7)$ & $46.8(2.1)^{* *}$ & $43.4(1.8)$ & $36.6(1.4)^{2}$ \\
\hline & VL & $47.3(2.5)$ & $42.5(1.0)$ & $51.6(2.0)$ & $50.2(0.6)$ & $47.7(2.3)$ \\
\hline \multirow[t]{4}{*}{ Middle } & DM & $29.5(1.5)$ & $33.6(3.7)$ & $34.9(1.0)$ & $36.7(2.5)$ & $31.9(1.5)$ \\
\hline & D & $34.8(0.9)$ & $38.6(1.1)$ & $46.3(3.3)^{* * *}$ & $47.3(1.5)^{* *}$ & $38.1(1.6)^{3}$ \\
\hline & $\mathbf{L}$ & $34.5(2.0)$ & $34.9(1.2)$ & $40.6(3.3)$ & $38.4(1.4)$ & $31.7(2.2)$ \\
\hline & VL & $51.7(1.7)$ & $55.3(6.3)$ & $58.7(2.2)$ & $56.8(1.2)$ & $50.9(1.2)$ \\
\hline \multirow[t]{4}{*}{ Caudal } & DM & $40.3(1.8)$ & $39.4(0.9)$ & $46.8(2.0)$ & $48.0(3.3)$ & $47.0(2.0)$ \\
\hline & D & $38.1(2.1)$ & $39.8(3.5)$ & $48.5(3.9)$ & $53.2(1.6)^{* *}$ & $48.0(2.9)$ \\
\hline & $\mathbf{L}$ & $38.7(1.8)$ & $33.9(1.3)$ & $40.3(1.8)$ & $40.5(1.4)$ & $33.1(1.9)^{3}$ \\
\hline & V & $60.0(3.4)$ & $56.5(1.6)$ & $65.1(4.0)$ & $65.6(4.5)$ & $56.8(2.8)$ \\
\hline
\end{tabular}

Animals were injected with vehicle $(0 \mathrm{~d}$ group), or with cocaine $(30 \mathrm{mg} / \mathrm{kg}$, i.p.) once (1 d group) or twice daily for 2 , 3 , or $4 \mathrm{~d}$, and were killed $30 \mathrm{~min}$ after the last injection. Data represent mean (SEM) OD values measured in dorsomedial (DM), dorsal (D), dorsolateral (DL), lateral (L), ventrolateral (VL), and ventral (V) regions at rostral, middle, and caudal striatal levels. Data were analyzed with ANOVA followed by Tukey-Kramer tests. Indicated are all significant differences between cocaine-treated groups and vehicle controls, and in most cases, significant differences between consecutive cocaine treatment days only. *, versus $0 \mathrm{~d}$ group; 1 , versus $1 \mathrm{~d}$ group; 2 , versus $2 \mathrm{~d}$ group; 3, versus $3 \mathrm{~d}$ group. **,11.22.33, $p<0.01 ; *, 1.2 .3, p<0.05$. 
Table 3. Regional variations in basal expression of substance $P$ (SP) and dynorphin (DYN) mRNA and in peak induction by cocaine of $c-f o s$, dynorphin, and substance P mRNA in striatum

\begin{tabular}{|c|c|c|c|c|c|c|c|}
\hline $\begin{array}{l}\text { Rostral } \\
\text { SP (basal) }\end{array}$ & $\underset{83.7}{\mathbf{D L}}$ & $>$ & $\underset{65.2}{\mathbf{D}}$ & $=$ & $\begin{array}{l}\text { VL } \\
58.2\end{array}$ & $>$ & $\begin{array}{l}\text { DM } \\
39.6\end{array}$ \\
\hline DYN (basal) ${ }^{a}$ & $\begin{array}{c}\mathrm{DL} \\
40.9\end{array}$ & $=$ & $\begin{array}{c}\mathrm{D} \\
41.2\end{array}$ & $<$ & $\underset{51.2}{\mathbf{D M}}$ & $\ll$ & $\underset{78.1}{\text { VL }}$ \\
\hline$c$-fos (peak) & $\underset{42.5}{\mathbf{D}}$ & $\gg$ & $\begin{array}{l}\text { DL } \\
22.4\end{array}$ & $\gg$ & $\begin{array}{c}\mathrm{VL} \\
10.6\end{array}$ & $=$ & $\begin{array}{c}\mathrm{DM} \\
7.1\end{array}$ \\
\hline DYN (peak) & $\underset{1.57}{\mathbf{D L}}$ & $=$ & $\underset{1.54}{\mathbf{D}}$ & $>$ & $\begin{array}{l}\mathrm{VL} \\
1.14\end{array}$ & $=$ & $\begin{array}{l}\mathrm{DM} \\
1.13\end{array}$ \\
\hline SP (peak) & $\underset{1.73}{\mathbf{D}}$ & $=$ & $\begin{array}{l}\text { DL } \\
1.42\end{array}$ & $=$ & $\underset{1.31}{\mathbf{D M}}$ & $=$ & $\begin{array}{l}\text { VI } \\
1.29\end{array}$ \\
\hline $\begin{array}{l}\text { Middle } \\
\text { SP (basal) }\end{array}$ & $\underset{86.1}{\mathbf{L}}$ & $>>$ & $\underset{58.7}{\mathbf{D}}$ & $\gg$ & $\begin{array}{c}\text { VL } \\
38.9\end{array}$ & $>$ & $\begin{array}{l}\text { DM } \\
26.3\end{array}$ \\
\hline DYN (basal) ${ }^{a}$ & $\begin{array}{c}\mathrm{D} \\
28.9\end{array}$ & $=$ & $\begin{array}{c}\mathrm{L} \\
34.5\end{array}$ & $\ll$ & $\underset{51.2}{\text { DM }}$ & $\ll$ & $\underset{65.8}{\mathbf{V L}}$ \\
\hline$c$-fos (peak) & $\underset{42.9}{\mathbf{D}}$ & $\gg$ & $\underset{13.4}{\mathrm{~L}}$ & $=$ & $\begin{array}{l}\text { DM } \\
11.0\end{array}$ & $=$ & $\begin{array}{c}\mathrm{VL} \\
10.4\end{array}$ \\
\hline DYN (peak) & $\underset{1.75}{\mathbf{D}}$ & $=$ & $\underset{1.47}{\mathbf{L}}$ & $=$ & $\begin{array}{l}\text { DM } \\
1.15\end{array}$ & $=$ & $\begin{array}{l}\mathrm{VL} \\
1.14\end{array}$ \\
\hline $\mathrm{SP}$ (peak) & $\underset{1.89}{\mathbf{D M}}$ & $=$ & $\underset{1.86}{\mathbf{D}}$ & $\gg$ & $\begin{array}{l}\text { L. } \\
1.40\end{array}$ & $\gg$ & $\begin{array}{c}\mathrm{VL} \\
0.96\end{array}$ \\
\hline $\begin{array}{l}\text { Caudal } \\
\text { SP (basal) }\end{array}$ & $\underset{78.0}{\mathbf{L}}$ & >> & $\underset{44.1}{\mathbf{V}}$ & $=$ & $\underset{40.8}{\text { D }}$ & $>$ & $\begin{array}{l}\text { DM } \\
23.7\end{array}$ \\
\hline DYN (basal) ${ }^{a}$ & $\underset{33.7}{\mathrm{D}}$ & $=$ & $\underset{40.2}{\mathrm{~L}}$ & $\ll$ & $\underset{61.5}{\text { DM }}$ & $\ll$ & $\begin{array}{l}\mathbf{V} \\
91.7\end{array}$ \\
\hline$c-f o s$ (peak) & $\underset{50.1}{\mathbf{D}}$ & $\gg$ & $\underset{17.0}{\text { DM }}$ & $=$ & $\underset{15.4}{\mathbf{L}}$ & $>$ & $\begin{array}{l}\mathrm{V} \\
1.2\end{array}$ \\
\hline DYN (peak) & $\underset{2.04}{\mathbf{D}}$ & $>>$ & $\underset{1.30}{\mathrm{~L}}$ & $=$ & $\begin{array}{l}\text { DM } \\
1.26\end{array}$ & $=$ & $\begin{array}{c}\mathrm{V} \\
1.17\end{array}$ \\
\hline $\mathrm{SP}$ (peak) & $\underset{2.30}{\mathbf{D}}$ & $=$ & $\underset{1.73}{\mathbf{D M}}$ & $=$ & $\underset{1.47}{\mathbf{L}}$ & $>$ & $\begin{array}{c}\mathrm{V} \\
0.67\end{array}$ \\
\hline
\end{tabular}

Basal expression (basal) was determined in animals that had received repeated vehicle injections. Peak induction (peak) was defined as follows: for dynorphin, as expression in the $2 \mathrm{~d}$ group divided by basal expression; for substance $\mathrm{P}$, as expression in the $1 \mathrm{~d}$ group divided by basal expression; for $\mathrm{c}-f o s$, as expression in the $1 \mathrm{~d}$ group minus basal expression (see Materials and Methods). Data represent (basal expression), or are based on (peak induction), mean OD values measured in dorsomedial (DM), dorsal (D), dorsolateral (DL), lateral (L), ventrolateral (VL), and ventral (V) striatal areas, at rostral, middle and caudal levels. Data were analyzed with ANOVA followed by Tukey-Kramer tests. $>, p$ $<0.01 ;>, p<0.05 ;=$, not significantly different.

${ }^{a}$ Note the inverse rank order for dynorphin basal expression.

Basal levels of dynorphin, substance $P$, and enkephalin expression were not correlated in the striatal regions examined. The peak induction of c-fos was negatively correlated with the basal expression of dynorphin, but was unrelated to the basal expression of substance $P$ or enkephalin. That is, the higher the basal dynorphin expression in a given area, the smaller the c-fos response to the first drug application in that area. Similar negative correlations were seen between basal dynorphin expression and peak induction of substance $P$ and dynorphin. On the other hand, a highly significant positive correlation existed between the peak induction of $c-f o s$ and the peak induction of dynorphin, indicating that a region with a large increase in c-fos expression on drug day 1 showed a large increase in dynorphin expression on drug day 2. A positive correlation was also seen between the peak induction of $\mathrm{c}-f o s$ and that of substance $\mathrm{P}$, indicating a regional covariation in $c-f o s$ and substance $\mathbf{P}$ response to the first cocaine injection, as well as between the peak induction of c-fos and that of enkephalin.

\section{Experiment 4: blockade of c-fos induction by dynorphin agonist}

Cocaine-induced $c$-fos $m R N A$ expression. In the three experiments presented above, we found an inverse relationship between striatal dynorphin and c-fos expression induced by cocaine, based on correlative analyses. The fourth experiment reported here describes the first test of a possible causal relationship between dynorphin and c-fos expression. We examined the influence of a dynorphin agonist on c-fos induction by a single cocaine injection in the region with the strongest $c$-fos response, the dorsal central striatal region, and the cingulate cortex. Figure 10 depicts pooled data from rostral, middle, and caudal striatal levels. The dynorphin agonist spiradoline, a spe- 


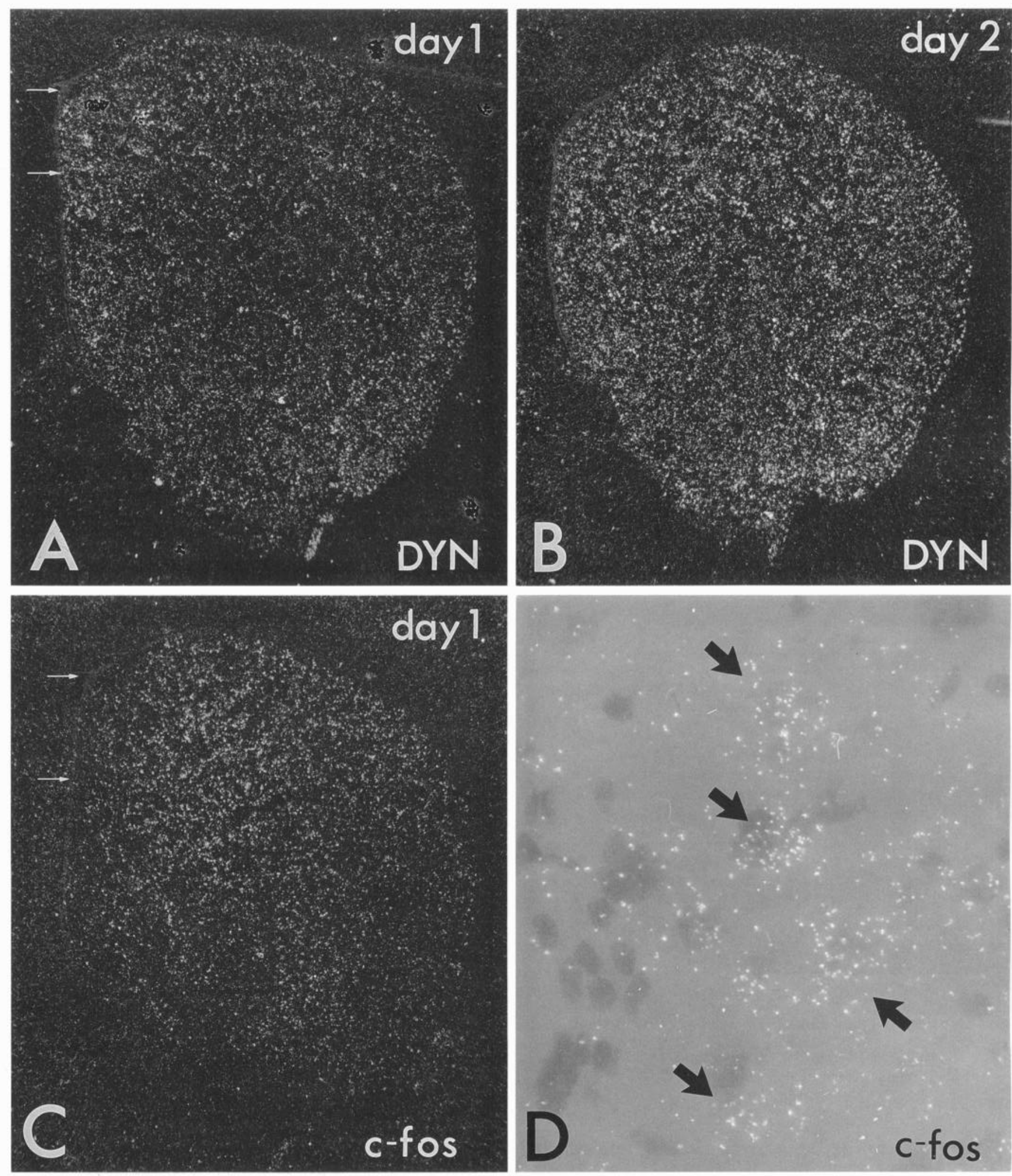

Figure 4. Basal and cocaine-induced dynorphin and c-fos mRNA expression. Dark-field photomicrographs (labeling seen as white dots) of midstriatal sections show basal dynorphin (DYN) expression (day 1; note that dynorphin expression in $1 \mathrm{~d}$ group corresponds to basal expression; see Results) $(A)$, dynorphin peak expression (after $30 \mathrm{mg} / \mathrm{kg}$ cocaine on drug day 2 ) $(B)$, and c-fos peak expression [after the first injection of $30 \mathrm{mg} /$ $\mathrm{kg}$ cocaine (day 1)] $(C)$. Comparison of basal dynorphin $(A)$ and c- $f o s$ mRNA labeling after cocaine $(C)$ on adjacent sections reveals the complementary patterns in the distribution of these two mRNAs (arrows indicate the edge of the lateral ventricle). In $D$, high-power dark-field photomicrograph of a region in the dorsal central striatum (from the section in C) shows silver grains (white dots) over c-fos-labeled cells (arrows). 


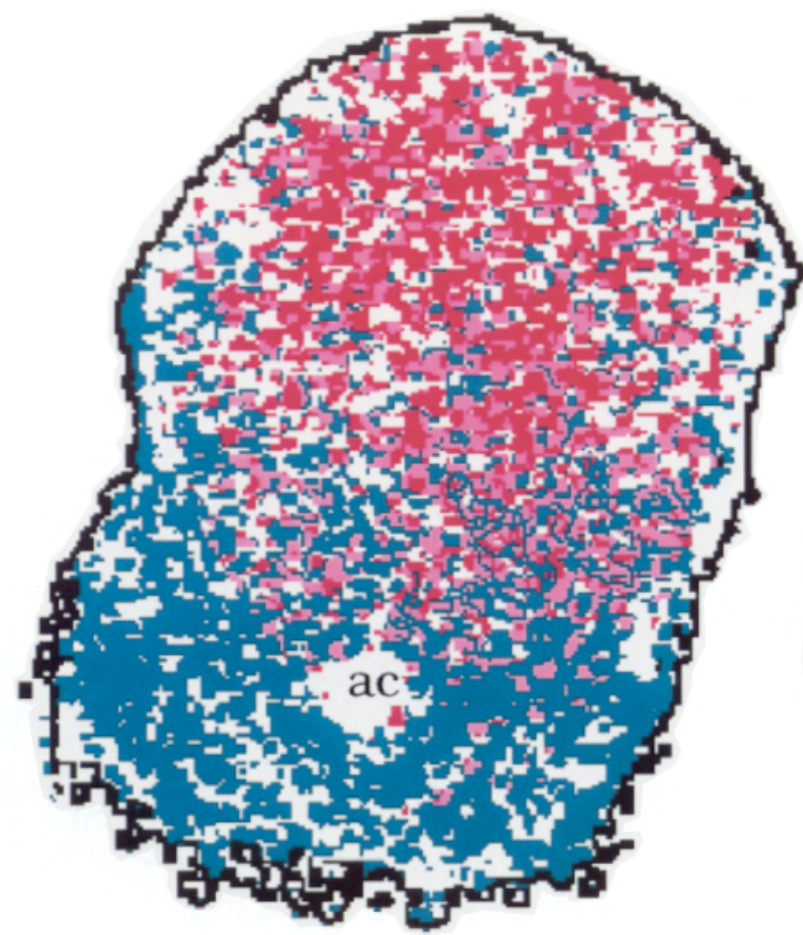

\section{A rostral}

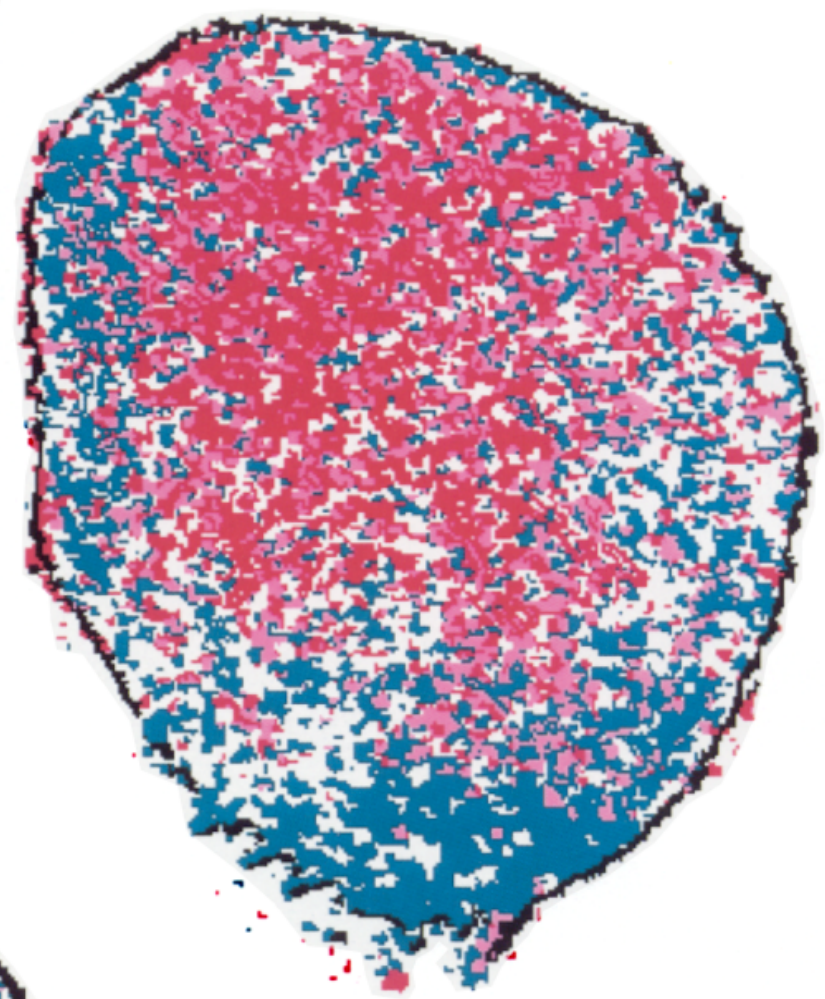

B middle

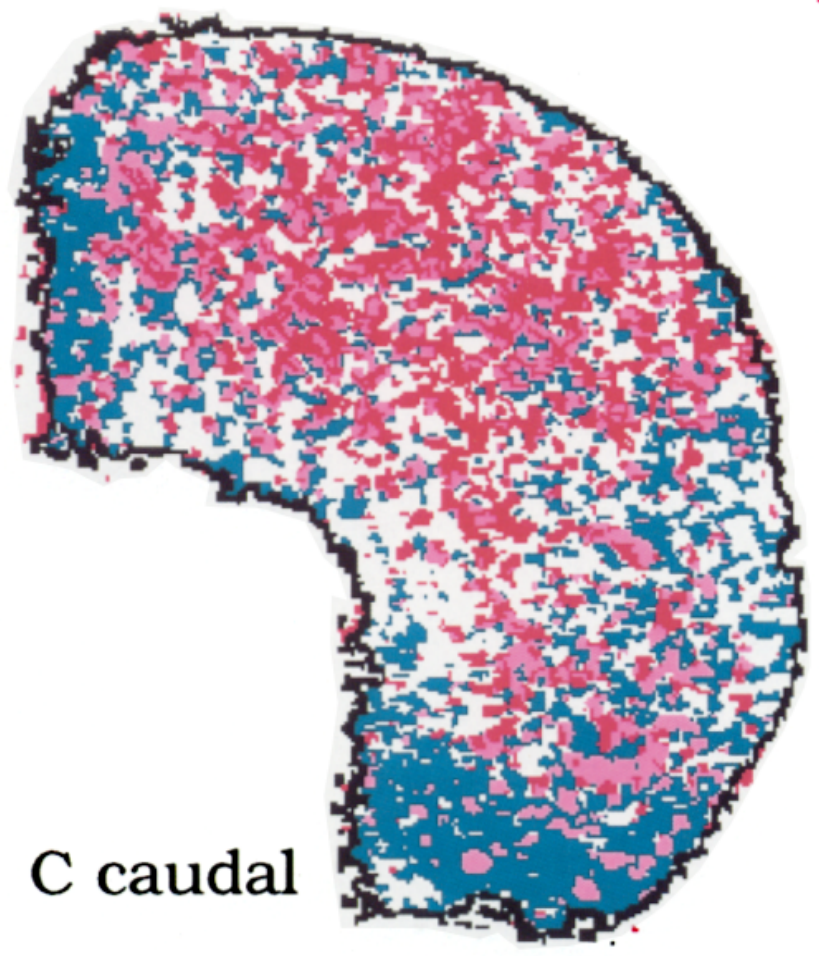

dynorphin mRNA $c$-fos mRNA

overlap

Figure 5. Regional patterns of basal dynorphin mRNA expression (blue) and c-fos mRNA induction by cocaine (red) in striatum. Areas of overlap are pink. The illustration is a composite of adjacent sections at the rostral $(A)$, middle $(B)$, and caudal striatal level $(C)$, from a rat killed 30 min after a single injection of $30 \mathrm{mg} / \mathrm{kg}$ cocaine (1 d group; note that dynorphin mRNA levels at this time point reflect basal expression; see Results). The composite image was constructed by thresholding the separate images of dynorphin and c-fos labeling at an $80 \%$ level, and then combining them. $a c$, anterior commissure. 

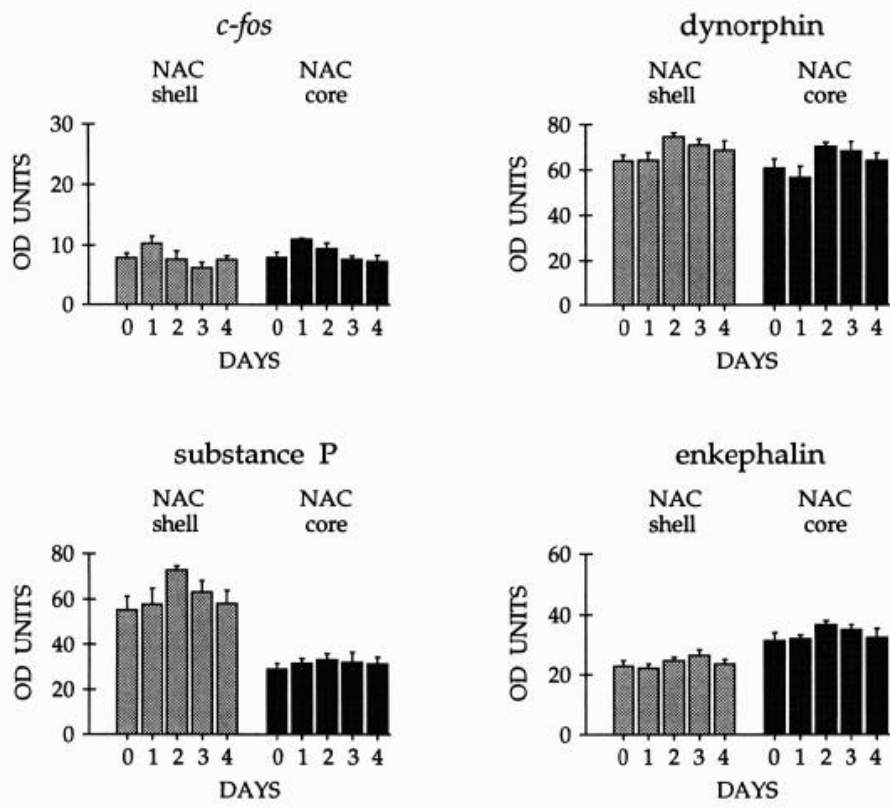

Figure 6. Influence of cocaine treatment on c-fos, dynorphin, substance $\mathrm{P}$, and enkephalin mRNA expression in nucleus accumbens $(N A C)$. OD values (mean + SEM) in nucleus accumbens shell and core regions are given for animals injected with vehicle ( $0 \mathrm{~d}$ group) or with cocaine ( 30 $\mathrm{mg} / \mathrm{kg}$, i.p.) either once ( $1 \mathrm{~d}$ group) or twice daily for $2-4 \mathrm{~d}$, and killed $30 \mathrm{~min}$ after the last injection.

cific $\kappa$-receptor agonist, blocked cocaine-induced c-fos expression in a dose-dependent manner. Administration of 5 and 10 $\mathrm{mg} / \mathrm{kg}$, but not the two lower doses, of spiradoline $15 \mathrm{~min}$ before the cocaine injection $(30 \mathrm{mg} / \mathrm{kg})$ significantly reduced striatal c-fos induction. In the cingulate cortex, c-fos labeling was reduced by $1-10 \mathrm{mg} / \mathrm{kg}$ of spiradoline. Spiradoline, in doses that blocked cocaine-induced c-fos expression in striatum (5-10 mg/ $\mathrm{kg}$ ), also prevented the behavioral activation (locomotion, rearing, sniffing) produced by the dopamine agonist. While such animals typically maintained a flat body position when left undisturbed, especially with the highest dose, they did orient to sensory stimuli.

\section{Discussion}

In the present experiments, the regulation by dopamine of striatal output pathways was analyzed in terms of the effects of the indirect dopamine receptor agonist cocaine on gene expression of c-fos, which serves as a marker of neuronal activation, and the neuropeptides dynorphin, substance $P$, and enkephalin, which serve as markers for striatonigral and striatopallidal neurons. The most important results are the following. (1) Cocaine produces a dose-dependent induction of c-fos following acute treatment, and elevation of dynorphin expression following repeated treatment. These changes display distinct regional patterns within the striatum. (2) An inverse relationship exists between dynorphin and cocaine-induced c-fos expression, as indicated by (i) the complementary regional patterns of basal dynorphin expression and c-fos induction after the first cocaine injection (i.e., striatal regions with low basal dynorphin expression show high levels of c-fos induction, and vice versa); (ii) the inverse time course of changes in expression of these two mRNAs during subsequent cocaine treatments (i.e., in areas of maximal initial c-fos induction, dynorphin expression increases in parallel to decreasing c-fos induction); and (iii) the ability of the dynorphin agonist spiradoline to block, in a dose-dependent manner, acute cocaine-induced c-fos expression. (3) Cocaine treatment also
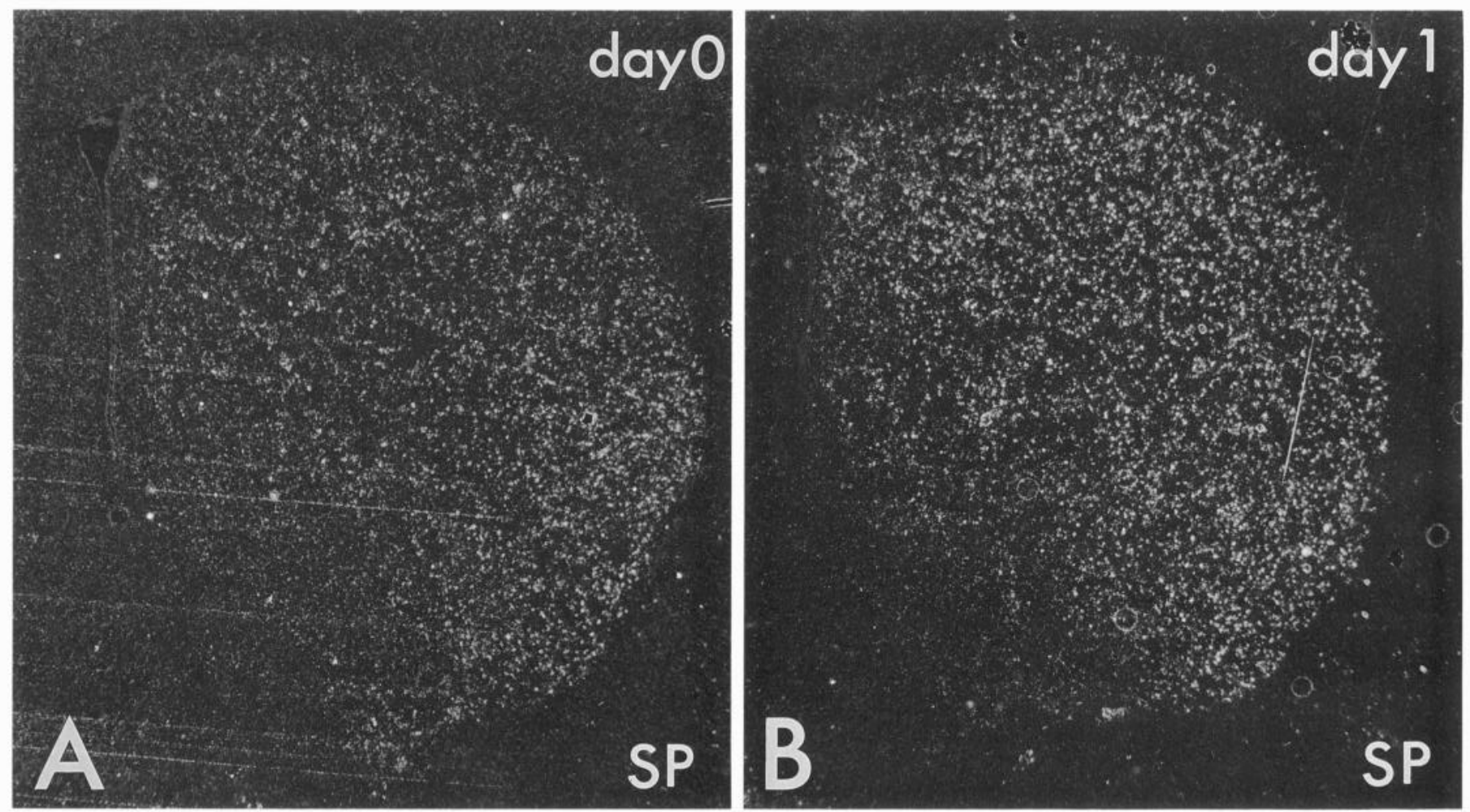

Figure 7. Basal and cocaine-induced substance P mRNA expression. Dark-field photomicrographs (labeling seen as white dots) of mid-striatal sections depict basal substance $\mathrm{P}(S P)$ expression (day 0$)(A)$ and substance P peak expression [after the first injection of $30 \mathrm{mg} / \mathrm{kg}$ cocaine (day 1)] $(B)$. 
$c-f o s$

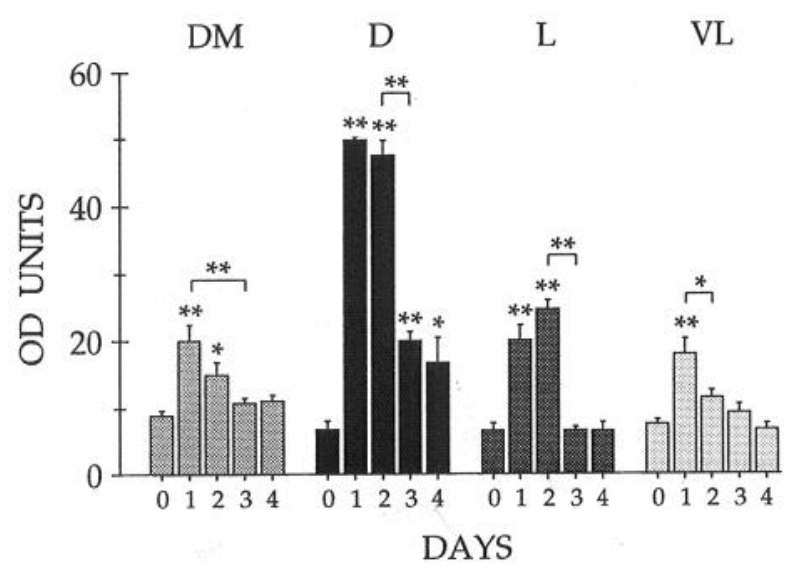

substance $\mathrm{P}$

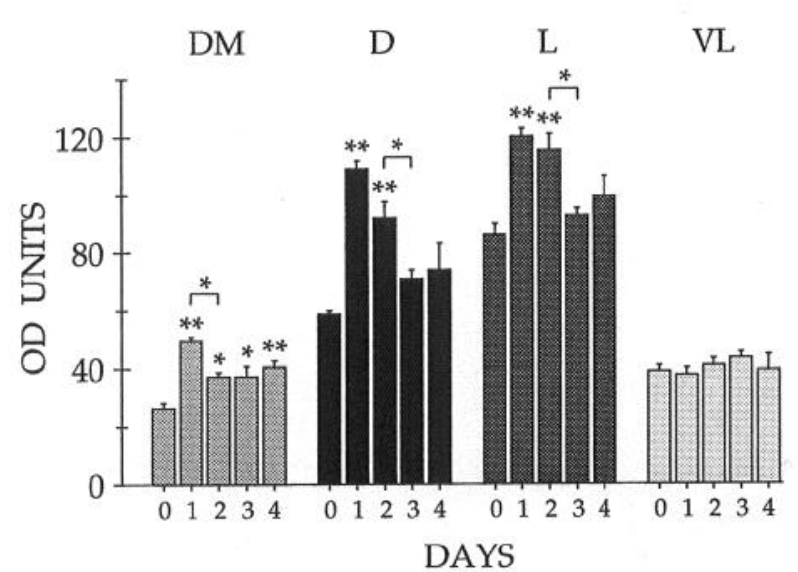

dynorphin

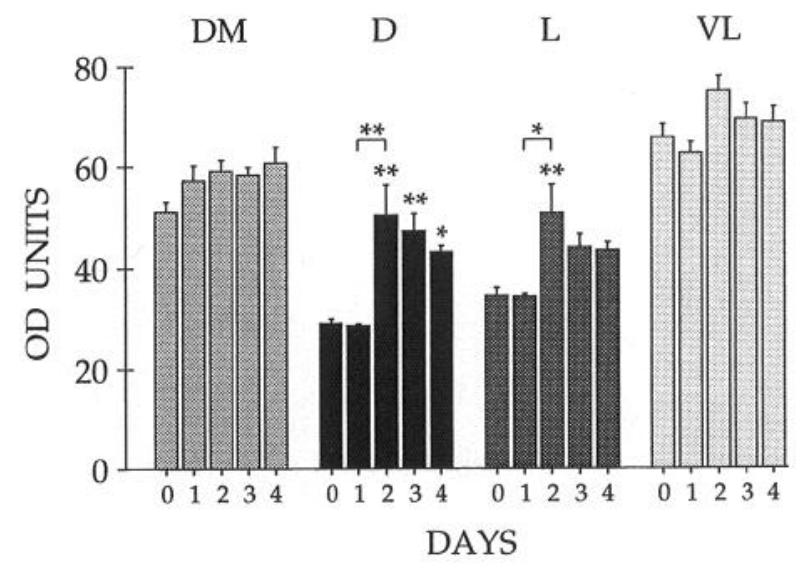

\section{enkephalin}

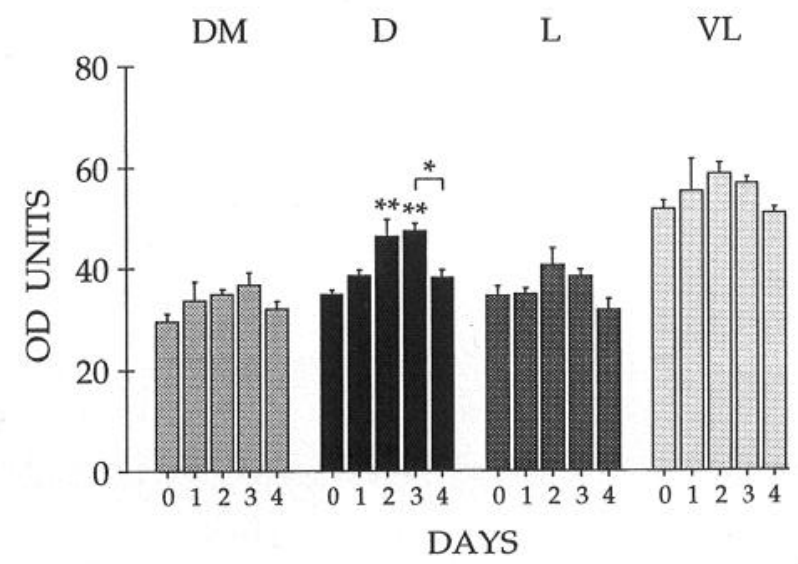

Figure 8. Time course of changes in striatal c-fos, dynorphin, substance $\mathrm{P}$, and enkephalin mRNA expression during repeated cocaine treatment. OD values (mean + SEM) in dorsomedial $(D M)$, dorsal $(D)$, lateral $(L)$, and ventrolateral $(V L)$ striatal regions at the middle level are shown for animals injected with cocaine $(30 \mathrm{mg} / \mathrm{kg}$, i.p.) either once (1 d group) or twice daily for $2-4 \mathrm{~d}$, or repeatedly with vehicle (0 d group), and killed $30 \mathrm{~min}$ after the last injection. Indicated are all significant differences between cocaine-treated groups and vehicle controls, and, in most cases, significant differences between consecutive cocaine treatment days only. Changes in expression of both c-fos and substance P mRNA display similar regional and temporal patterns: a maximal induction in the dorsal central region following the first drug application and significantly reduced induction from treatment days 2 or 3 on. In contrast, changes in dynorphin expression follow an inverse time course. That is, the expression is maximally increased on treatment day 2 and remains elevated through day 4 in the region with the strongest response (i.e., in the dorsal central region). The increase in dynorphin expression is limited to the areas with relatively low basal dynorphin expression and the strongest c-fos response on treatment day 1 . The enkephalin expression displays a minor and transient increase in the dorsal central region. ${ }^{* *}, p<0.01 ;{ }^{*}, p<0.05$ (ANOVA, Tukey-Kramer test).

produces a marked increase in striatal substance $\mathrm{P}$ expression that, in both its regional patterns and time course of induction, is very similar to that of c-fos induction. Minor, but statistically significant, increases in enkephalin mRNA levels are also seen, which are similar regionally, but not temporally, to the c-fos response. The specific inverse relationship between dynorphin and c-fos expression in response to cocaine treatment suggests that dynorphin may be involved in regulating the response of striatonigral neurons to dopamine receptor stimulation.

\section{Altered striatal gene regulation in response to cocaine}

Pharmacologic treatment with dopamine agonists provides information about dopamine receptor-mediated regulation of the two main populations of striatal projection neurons, striatonigral and striatopallidal neurons, by the specific effects on levels of mRNAs they express. For the most part, striatonigral neurons contain dynorphin, substance $\mathrm{P}$ and the $\mathrm{D}_{1}$ dopamine receptor, whereas striatopallidal neurons contain enkephalin and the $\mathrm{D}_{2}$ dopamine receptor. In the 6-hydroxydopamine-lesioned striatum, dynorphin and substance P (Gerfen et al., 1990), and c-fos (Robertson et al., 1990) are regulated in striatonigral neurons by $D_{1}$ agonist treatment, whereas enkephalin is regulated by $D_{2}$ agonist treatment (Gerfen et al., 1990). The patterns of altered gene expression observed in the present study are consistent with a predominant effect of cocaine on striatonigral neurons through a $D_{1}$ receptor-mediated process. First, as reported here and elsewhere (Sivam, 1989; Smiley et al., 1990; Hurd et al., 1992), cocaine produces an elevation of both dynorphin and substance $\mathrm{P}$, which are contained in striatonigral neurons. Second, previous studies have demonstrated that cocaine admin- 
B

\section{A}

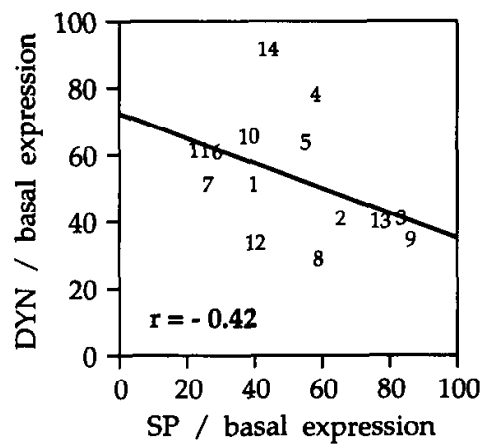

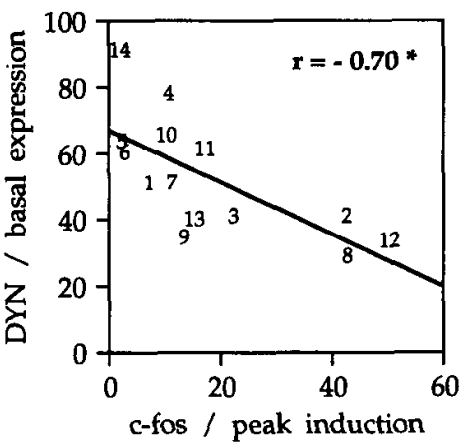

$\mathrm{D}$

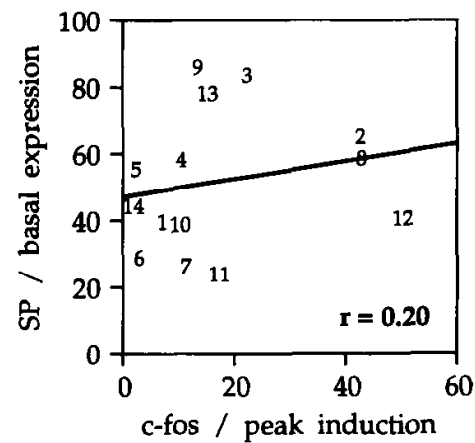

C

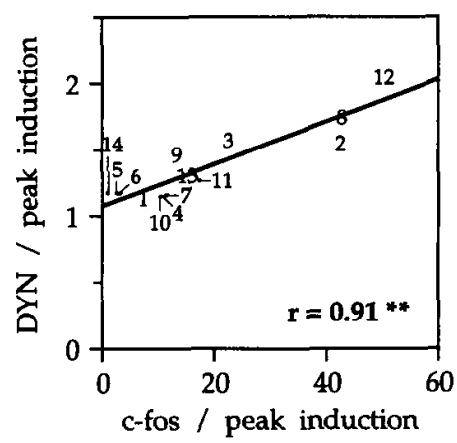

$\mathrm{E}$

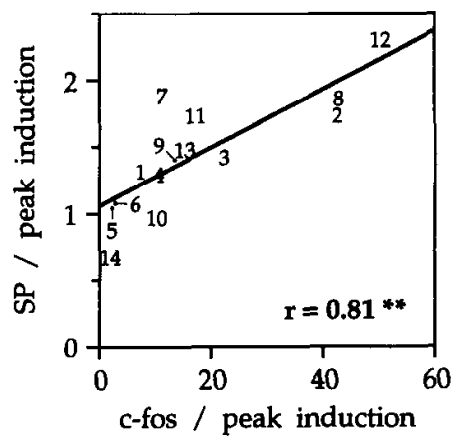

Figure 9. Regional correlations between basal expression and peak induction by cocaine of c-fos, dynorphin, and substance P mRNA in striatum. Scatter plots depict correlations (or lack of) between basal substance $\mathrm{P}(S P)$ and basal dynorphin $(D Y N)$ expression $(A)$, and between c-fos peak induction and basal dynorphin expression $(B)$, dynorphin peak induction $(C)$, basal substance $P$ expression $(D)$, and substance $P$ peak induction $(E)$ in the following 14 striatal areas. Rostral level: dorsomedial $(I)$, dorsal central (2), dorsolateral (3), ventrolateral (4), nucleus accumbens shell (5) and core (6). Middle level: dorsomedial (7), dorsal central (8), lateral (9), ventrolateral (10). Caudal level: dorsomedial (11), dorsal central (12), lateral (13), ventral (14). Data represent, for basal expression, mean OD values from vehicle-treated animals (0 $\mathrm{d}$ group), and for peak induction, expression on day 1 minus basal expression (c-fos), expression on day 2 divided by basal expression (dynorphin), or expression on day 1 divided by basal expression (substance P). Values are indicated by the position of the area's number on the scatter plot. This analysis shows the negative correlation between basal dynorphin expression and c-fos peak induction, the positive correlations between c-fos peak induction and dynorphin peak induction, and substance $P$ peak induction, as well as no regional correlation between basal substance $P$ expression and basal dynorphin expression, and c-fos peak induction. $r$, Pearson's correlation coefficient. ${ }^{* *}, p<0.01 ;{ }^{*}, p<0.05(t$ test $)$.

Table 4. Correlations between basal expression and peak induction by cocaine of c-fos, dynorphin, substance $P$, and enkephalin mRNA in the 14 striatal regions

Basal Peak

\begin{tabular}{|c|c|c|c|c|c|c|c|}
\hline & \multicolumn{3}{|l|}{ Basal } & \multicolumn{4}{|l|}{ Peak } \\
\hline & Dynorphin & Substance $P$ & Enkephalin & c-fos & Dynorphin & Substance $P$ & Enkephalin \\
\hline \multicolumn{8}{|l|}{ Basal } \\
\hline Dynorphin & - & & & & & & \\
\hline Substance P & -0.42 & - & & & & & \\
\hline Enkephalin & 0.53 & -0.03 & - & & & & \\
\hline \multicolumn{8}{|l|}{ Peak } \\
\hline c-fos & $-0.70^{*}$ & 0.20 & -0.03 & - & & & \\
\hline Dynorphin & $-0.72^{*}$ & 0.32 & -0.07 & $0.91^{* *}$ & - & & \\
\hline Substance $\mathbf{P}$ & $-0.73^{*}$ & -0.04 & -0.33 & $0.81^{* *}$ & $0.72^{*}$ & - & \\
\hline Enkephalin & -0.64 & 0.19 & -0.15 & $0.77^{*}$ & $0.77^{*}$ & 0.60 & - \\
\hline
\end{tabular}

The correlation analysis was performed between basal expression of each neuropeptide (basal) and peak induction of these neuropeptides (peak) in each of the 14 striatal regions examined. Basal expression was defined as expression in vehicle controls. Peak induction was defined as follows: for dynorphin, as expression in the $2 \mathrm{~d}$ group divided by basal expression; for substance $P$, as cxpression in the 1 d group divided by basal cxpression; for c-fos, as expression in the 1 d group minus basal expression. Values are presented as $r$, Pearson's correlation coefficient. ${ }^{*}, p<0.01 ;{ }^{*}, p<0.05(t$ test). 
spiradoline $(\mathrm{mg} / \mathrm{kg})$ prior to cocaine

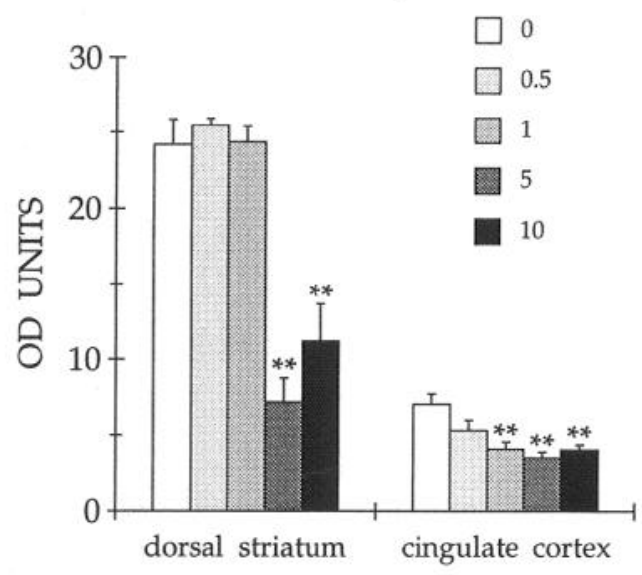

Figure 10. Dose-dependent blockade of cocaine-induced c-fos mRNA expression by the dynorphin agonist spiradoline. OD values (mean + SEM) in the dorsal central striatum and in the cingulate cortex are depicted for groups of rats that had received an injection of $0-10 \mathrm{mg}$ $\mathrm{kg}$ of spiradoline (U-62066) $15 \mathrm{~min}$ prior to cocaine administration (30 $\mathrm{mg} / \mathrm{kg}$ ). The values presented are means from rostral, middle, and caudal striatal sections. The injection of the two higher doses (5 and $10 \mathrm{mg}$ ) $\mathrm{kg}$ ) of spiradoline blocks completely the behavioral activation induced by cocaine (locomotion, sniffing, rearing) and reduces significantly striatal c-fos induction by this drug. The c-fos signal in the cingulate cortex is also decreased by the dynorphin agonist. ${ }^{* *}, p<0.01$, compared to controls $[0 \mathrm{mg} / \mathrm{kg}$ (vehicle) + cocaine] (ANOVA, Dunnett's test).

istration induces Fos protein principally in striatal neurons retrogradely labeled from the substantia nigra (Cenci et al., 1992). Third, several studies have shown that c-fos expression produced by cocaine or other dopamine reuptake inhibitors is blocked by $\mathrm{D}_{1}$ antagonist treatment (Graybiel et al., 1990; Young et al., 1991; Morelli et al., 1992). Finally, in the present study, the time course and regional patterns of c-fos induction parallel those of altered substance P mRNA expression. While these data all point to a predominant effect of cocaine on gene regulation in striatonigral neurons, the small, yet significant, elevation of enkephalin expression reported here suggests some influence on striatopallidal neurons as well. As pointed out, the changes in gene regulation after cocaine treatment are consistent with a principal action of this drug on dopamine transmission (see also Sivam, 1989). However, cocaine also affects reuptake of other monoamines, and it is therefore possible that a nondopaminergic effect contributes to the changes in gene expression observed here.

As discussed, it is reasonable to conclude that cocaine treatment activates $D_{1}$ dopamine receptors on striatonigral neurons to elevate c-fos, substance $\mathrm{P}$, and dynorphin mRNA levels in these neurons. However, the present data suggest that these genes are differentially regulated. For example, distinct regional patterns in the basal expression of substance $P$ and dynorphin exist. In addition, whereas both c-fos and substance P mRNA levels are elevated within $30 \mathrm{~min}$ after a single injection of cocaine, the elevation of dynorphin mRNA levels is delayed. Such a dissociation is also observed at later time points during repeated cocaine treatment, in that c-fos and substance P mRNA levels parallel one another in declining, while dynorphin mRNA levels remain elevated. Thus, in individual striatonigral neurons the two neuropeptide genes encoding substance $P$ and dynorphin appear to be under different regulatory control.
Inverse relationship between cocaine-induced c-fos and dynorphin expression

In the present study, the regional patterns of c-fos induction are shown to be inversely related to basal levels of dynorphin mRNA expression. Rank ordering striatal regions by their basal dynorphin expression shows that ventrolateral and dorsomedial regions express significantly higher levels of dynorphin mRNA than dorsal central and lateral regions. This pattern is complementary to the rank ordering of levels of c-fos induction in response to a single cocaine treatment. Thus, c-fos induction is greatest in dorsal and dorsolateral regions and significantly lower in the ventrolateral and dorsomedial striatum. Mapping the distribution of the striatal regions showing the highest basal levels of dynorphin expression with the regions in which c-fos is induced by a single cocaine injection illustrates these complementary patterns (Fig. 5). The specificity of this relationship is provided by the lack of a similar relationship between basal substance P mRNA levels and c-fos induction patterns. Further evidence for the inverse relationship between c-fos induction and dynorphin expression is provided by the temporal patterns of changes in these mRNAs following repeated injections of cocaine. Thus, with successive daily injections of this drug, dynorphin mRNA levels increase, and c-fos mRNA levels decrease in the dorsal and lateral striatal regions, regions in which basal dynorphin expression is lowest and c-fos induction is highest after a single cocaine treatment. On the other hand, levels of substance P mRNA appear to parallel both regionally and temporally the initial increase and subsequent decrease in c-fos induction.

These data suggest that dynorphin acts to control the response of striatal neurons, as indicated by the induction of c-fos mRNA, to dopamine stimulation. According to such a hypothesis, neurons in regions with high basal expression of dynorphin would show a limited response to dopamine stimulation. Neurons in regions with relatively low basal dynorphin expression would show a greater response. This greater response would trigger increased expression and release of dynorphin, which, in turn, would downregulate the response to future dopamine stimulation. Presently, it is not certain that chronic cocaine treatment produces changes in striatal dynorphin release. However, it has been shown that increased dynorphin mRNA levels are accompanied by increased dynorphin peptide levels in striatum after treatment with cocaine or other dopamine agonists (Hanson et al., 1988; Li et al., 1988; Sivam, 1989; Gerfen et al., 1991). In addition, our finding of a blockade of cocaine-induced c-fos expression by systemic application of the dynorphin agonist spiradoline-while inconclusive in terms of site of action-is consistent with this proposed role of dynorphin. Moreover, recent results by Engber et al. (1991), which showed that spiradoline inhibits $D_{1}$ (but not $D_{2}$ ) agonist-induced rotational behavior after a nigrostriatal lesion, further support this hypothesis.

There are several possible ways by which dynorphin could control the responsiveness of striatal neurons. (1) Dynorphin may exert an inhibitory effect on dopamine release through presynaptic mechanisms. Dynorphin is a $k$-opioid receptor agonist (Chavkin et al., 1982; Corbett et al., 1982), and $\kappa$-receptor binding is present throughout the striatum (Mansour et al., 1987; Tempel and Zukin, 1987). In vivo and in vitro studies have reported dynorphin- or $k$-agonist-induced reduction of dopamine release within the striatum, suggesting a presynaptic localization of $\kappa$-receptors on nigrostriatal afferent terminals 
(Mulder et al., 1984; Broderick, 1987; Di Chiara and Imperato, 1988; Werling et al., 1988). However, the minimal reduction of striatal $\kappa$-receptor binding that occurs after destruction of nigrostriatal dopamine terminals (Eghbali et al., 1987) argues against such presynaptic receptor localization. (2) Gauchy et al. (1991) have reported that dynorphin and $\kappa$-agonists inhibit AChmediated dopamine release within the striatum, which raises the possibility of cholinergic involvement. (3) Another presynaptic mechanism might involve striatal dynorphin acting to reduce corticostriatal input. Findings from studies of the hippocampus indicate that dynorphin may be released by dentate granule cells to presynaptically reduce glutamate input from the cortex to the dentate gyrus (Wagner et al., 1992). A similar role for dynorphin in the striatum is conceivable. Since striatal neurons are driven by cortical input (and dopamine is thought to modulate this input), presynaptic inhibition of cortical input would provide a very powerful mechanism to control striatal excitability. However, such an interaction remains to be demonstrated. (4) Alternatively, dynorphin could influence the response of striatal neurons by postsynaptic mechanisms, such as the control of ion channels and/or adenylate cyclase activity. Opioid receptors are coupled through G-proteins to second messenger systems and ion channels (West and Miller, 1983; Childers, 1991). Dynorphin and $k$-agonists have been shown to inhibit $\mathrm{Ca}^{2+}$ influx (e.g., Gross and Macdonald, 1987; Attali et al., 1989a) and reduce adenylate cyclase activity in various neuronal tissues including striatal neurons (Gentleman et al., 1983; Attali et al., 1989b; Eriksson et al., 1990; but see Schoffelmeer et al., 1988). Since $\mathrm{Ca}^{2+}$ and cAMP levels are involved in the regulation of, for example, $c-f o s$ induction (see below), activation of postsynaptic $\boldsymbol{k}$-receptors could thus also provide a direct mechanism for dynorphin to control gene expression.

Therefore, there are several potential mechanisms by which dynorphin could downregulate the responsiveness of striatal neurons. Consistent with this hypothesis, chronic amphetamine treatment, which also produces increased striatal dynorphin expression (Hanson et al., 1987, 1988; Li et al., 1988), has been found to render striatal neurons subsensitive to dopaminergic input (Kamata and Rebec, 1985).

\section{Functional significance}

Studies of altered gene regulation in striatonigral neurons following a variety of pharmacologic manipulations have consistently shown that stimulation of $D_{1}$ receptors on these neurons increases levels of mRNAs encoding Fos and the neuropeptides dynorphin and substance $P$. In order to relate these changes to function, it is necessary to consider what these specific alterations in mRNA levels reflect in the context of the pharmacologic manipulations employed.

The induction of c-fos and other immediate-early genes in neurons is thought to reflect increased neuronal activity. This is based on findings that a number of experimental manipulations that activate neuronal systems, including drug application, electrical stimulation, and sensory stimulation, lead to a rapid and transient induction of c-fos, as well as on findings that depolarization and elevated intracellular levels of cAMP and $\mathrm{Ca}^{2+}$ increase c-fos expression in many brain systems (for reviews, see Morgan and Curran, 1989, 1991; Sheng and Greenberg, 1990). Therefore, it has been suggested that c-fos mRNA or the Fos protein could serve as a marker for mapping neuronal activity and tracing functional pathways (Sagar et al., 1988; Dragunow and Faull, 1989).
In the dopamine-depleted striatum, $D_{1}$ receptor activation produces $\mathrm{c}-$ fos induction in striatonigral neurons (Robertson et al., 1990, 1992). In contrast, c-fos induction in striatopallidal neurons results from $\mathrm{D}_{2}$ receptor blockade in the normally innervated striatum (Dragunow et al., 1990; Robertson et al., 1992), probably due to release from the presumed tonic inhibition dopamine exerts through the $\mathrm{D}_{2}$ receptor on these neurons. Thus, the induction of c-fos appears to reflect an excitatory response of striatal neurons. After a single high dose of cocaine, the temporal pattern of striatal c-fos mRNA induction parallels closely the increased extracellular dopamine levels in the striatum (e.g., Kuczenski and Segal, 1992) as well as behavioral activation (e.g., Kalivas and Duffy, 1993), with c-fos mRNA, dopamine levels, and behavioral activation reaching peak levels by $20-40 \mathrm{~min}$ and returning to basal levels by $90 \mathrm{~min}$ to $2 \mathrm{hr}$ after the injection (H. Steiner and C. R. Gerfen, unpublished observations). Since c-fos levels are very low in the normal striatum, the induction of $c$-fos by cocaine treatment therefore presumably reflects the increase in dopamine activation of $D_{1}$ receptors on striatonigral neurons.

On the other hand, the present results demonstrate that other mRNAs, specifically dynorphin, display a temporal pattern of elevation that is not tightly correlated with c-fos mRNA levels and therefore not with the level of activation of striatonigral neurons. It is suggested that such changes in gene regulation, that appear with a delay and persist beyond the period of direct drug action, reflect a compensatory response-in the case of dynorphin in striatonigral neurons, to regulate the responsiveness of those neurons to subsequent dopamine stimulation. This is supported by the reduction in cocaine-induced c-fos as dynorphin levels increase over days and by the ability of the dynorphin agonist to block acute cocaine-induced c-fos expression.

The regional variations in the basal and drug-induced levels of mRNAs expressed by striatal neurons provide further information about the functional organization of the striatum. First, as shown here, there are significant differences between striatal regions in the basal levels of dynorphin and substance $P$ expression. Since the levels of dynorphin and substance P mRNA are regulated, at least in part, by $\mathrm{D}_{1}$ dopamine receptor-mediated mechanisms (Gerfen et al., 1990), regional differences in basal levels may reflect normal differences in dopamine neurotransmission and/or interactions with other transmitter systems.

Second, the present results - by demonstrating different basal levels of dynorphin mRNA and a differential influence of cocaine treatment on gene regulation-especially suggest functional differences between dorsal and ventral striatal regions. The hypothesis presented here, that dynorphin levels reflect a compensatory mechanism to limit the response of neurons to dopamine neurotransmission, might lead to the prediction of greater basal dopamine release in areas with higher basal dynorphin expression. While this might be the case in some striatal regions (e.g., patch vs. matrix in the dorsal striatum), the situation is more complex with respect to dorsal-ventral differences. In fact, a comparison of extracellular dopamine levels between the dorsal central striatum, which displays low basal dynorphin expression, and the ventral striatum/nucleus accumbens, with high basal dynorphin expression, shows results opposite to the prediction: higher basal dopamine levels in the dorsal striatum than in the nucleus accumbens (Kuczenski and Segal, 1992). However, these regions also differ in the distribution of the dopaminc transporter, which functions to remove dopamine 
from the extracellular space. Recent studies have shown that the density of the dopamine transporter is higher in the dorsal than in the ventral striatum (Richfield, 1991; Boja et al., 1992). Thus, although there may be more dopamine released in the dorsal striatum, the dopamine transporter could conceivably limit its action in this region, whereas in the ventral striatum, lower levels of dopamine release could have a greater (prolonged) action, owing to the relatively lower levels of the transporter. This could result in higher levels of basal dynorphin expression in the ventral striatum. Cocaine is thought to block the dopamine transporter (Heikkila et al., 1975; Taylor and Ho, 1978; Missale et al., 1985), and the dorsally restricted c-fos induction after cocaine treatment may reflect, in part, the distribution pattern of the transporter. However, cocaine is not without effect on dopamine levels in the ventral striatum. In fact, the relative increase in dopamine levels produced by cocaine is even greater in the ventral striatum (Di Chiara and Imperato, 1988; Kuczenski and Segal, 1992), due to the lower basal level in this region (Kuczenski and Segal, 1992). Based on the present data, it would be suggested that the higher basal dynorphin levels in the ventral striatum blunt the neuronal response to cocaine in this region, which would lead to a reduced effect on gene regulation.

\section{Conclusions}

Previous analysis of pharmacologically altered gene regulation has shown that the induction of c-fos or the elevation of neuropeptide mRNA levels in striatonigral neurons occurs through the activation of $D_{1}$ dopamine receptors expressed by these neurons. The present results suggest that changes in the expression of c-fos and substance $\mathrm{P}$ are an immediate response to receptor-mediated activation, and that changes in dynorphin expression are a compensatory response that regulates the responsiveness to dopamine in striatonigral neurons.

\section{References}

Attali B, Saya D, Nah S-Y, Vogel Z (1989a) $\kappa$ opiate agonists inhibit $\mathrm{Ca}^{2+}$ influx in rat spinal cord-dorsal root ganglion cocultures. J Biol Chem 264:347-353.

Attali B, Saya D, Vogel Z (1989b) $k$-opiate agonists inhibit adenylate cyclase and produce heterologous desensitization in rat spinal cord. J Neurochem 52:360-369.

Bannon MJ, Elliott PJ, Bunney EB (1987) Striatal tachykinin biosynthesis: regulation of mRNA and peptide levels by dopamine agonists and antagonists. Mol Brain Res 3:31-37.

Beckstead RM, Kersey KS (1985) Immunohistochemical demonstration of differential substance P-, met-enkephalin-, and glutamic acid decarboxylase-containing cell and axon distributions in the corpus striatum of the cat. J Comp Neurol 232:481-498.

Boja JW, Mitchell WM, Patel A, Kopajtic TA, Carroll FI, Lewin AH, Abraham P, Kuhar MJ (1992) High-affinity binding of [ ${ }^{125}$ I]RTI55 to dopamine and serotonin transporters in rat brain. Synapse 12: 27-36.

Broderick PA (1987) Striatal neurochemistry of dynorphin-(1-13): in vivo electrochemical semidifferential analyses. Neuropeptides 10:369386.

Brownstein MJ, Mroz EA, Tappaz ML, Leeman SE (1977) On the origin of substance $P$ and glutamic acid decarboxylase (GAD) in the substantia nigra. Brain Res 135:315-323.

Cenci MA, Campbell K, Wictorin K, Björklund A (1992) Striatal c-fos induction by cocainc or apomorphine occurs preferentially in output neurons projecting to the substantia nigra in the rat. Eur J Neurosci 4:376-380.

Chavkin C, James IF, Goldstein A (1982) Dynorphin is a specific endogenous ligand of the kappa opioid receptor. Science 215:413415 .
Childers SR (1991) Opioid receptor-coupled second messenger systems. Life Sci 48:1991-2003.

Corbett AD, Paterson SJ, McKnight AT, Magnan J, Kosterlitz HW (1982) Dynorphin ${ }_{1-8}$ and dynorphin ${ }_{1.9}$ are ligands for the $k$-subtype of opiate receptor. Nature 299:79-81.

Di Chiara G, Imperato A (1988) Drugs abused by humans preferentially increase synaptic dopamine concentrations in the mesolimbic system of freely moving rats. Proc Natl Acad Sci USA 85:5274-5278.

Dragunow M, Faull R (1989) The use of c-fos as a metabolic marker in neuronal pathway tracing. J Neurosci Methods 29:261-265.

Dragunow M, Robertson GS, Faull RLM, Robertson HA, Jansen K (1990) $D_{2}$ dopamine receptor antagonists induce Fos and related proteins in rat striatal neurons. Neuroscience 37:287-294.

Eghbali M, Santoro C, Paredes W, Gardner EL, Zukin RS (1987) Visualization of multiple opioid-receptor types in rat striatum after specific mesencephalic lesions. Proc Natl Acad Sci USA 84:65826586.

Engber TM, Boldry RC, Chase TN (1991) The $\kappa$-opioid receptor agonist spiradoline differentially alters the rotational response to dopamine $D_{1}$ and $D_{2}$ agonists. Eur J Pharmacol 200:171-173.

Eriksson PS, Hansson E, Ronnback L (1990) Opiate receptors in neuronal primary cultures. Neuropharmacology 29:799-804.

Gauchy C, Desban M, Krebs MO, Glowinski J, Kemel ML (1991) Role of dynorphin-containing neurons in the presynaptic inhibitory control of the acetylcholine-evoked release of dopamine in the striosomes and the matrix of the cat caudate nucleus. Neuroscience 41 : 449-458.

Gentleman S, Parenti M, Neff NH, Pert CB (1983) Inhibition of dopamine-activated adenylate cyclase and dopamine binding by opiate receptors in rat striatum. Cell Mol Neurobiol 3:17-26.

Gerfen CR (1992) The neostriatal mosaic: multiple levels of compartmental organization in the basal ganglia. Annu Rev Neurosci 15: 285-320.

Gerfen CR, Young WS III (1988) Distribution of striatonigral and striatopallidal peptidergic neurons in both patch and matrix compartments: an in situ hybridization histochemistry and fluorescent retrograde tracing study. Brain Res 460:161-167.

Gerfen CR, Engber TM, Mahan LC, Susel Z, Chase TN, Monsma FJ Jr, Sibley DR (1990) $D_{1}$ and $D_{2}$ dopamine receptor-regulated gene expression of striatonigral and striatopallidal neurons. Science 250: 1429-1432.

Gerfen CR, McGinty JF, Young WS III (1991) Dopamine differentially regulates dynorphin, substance $P$ and enkephalin expression in striatal neurons: in situ hybridization histochemical analysis. J Neurosci 11:1016-1031.

Graybiel AM, Moratalla R, Robertson HA (1990) Amphetamine and cocaine induce drug-specific activation of the c-fos gene in striosomematrix compartments and limbic subdivisions of the striatum. Proc Natl Acad Sci USA 87:6912-6916.

Gross RA, Macdonald RL (1987) Dynorphin A selectively reduces a large transient ( $\mathrm{N}$-type) calcium current of mouse dorsal root ganglion neurons in cell culture. Proc Natl Acad Sci USA 84:5469-5473.

Hanson GR, Merchant KM, Letter AA, Bush L, Gibb JW (1987) Methamphetamine-induced changes in the striatal-nigral dynorphin system: role of D-1 and D-2 receptors. Eur J Pharmacol 144:245246.

Hanson GR, Merchant KM, Letter AA, Bush L, Gibb JW (1988) Characterization of methamphetamine effects on the striatal-nigral dynorphin system. Eur J Pharmacol 155:11-18.

Heikkila RE, Orlansky HO, Cohen G (1975) Studies on the distinction between uptake inhibition and release of $\left[{ }^{3} \mathrm{H}\right]$ dopamine in rat brain tissue slices. Biochem Pharmacol 24:847-852.

Hong JS, Yang H-YT, Fratta W, Costa E (1978) Rat striatal methionine-enkephalin content after chronic treatment with cataleptogenic and noncataleptogenic drugs. J Pharmacol Exp Ther 205:141-147.

Hurd YL, Brown EE, Finlay JM, Fibiger HC, Gerfen CR (1992) Cocaine self-administration differentially alters mRNA expression of striatal peptides. Mol Brain Res 13:165-170.

Kalivas PW, Duffy P (1993) Time course of extracellular dopamine and behavioral sensitization to cocaine. I. Dopamine axon terminals. J Neurosci 13:266-275.

Kamata K, Rebec GV (1985) Iontophoretic evidence for subsensitivity of postsynaptic dopamine receptors following long-term amphetamine administration. Eur J Pharmacol 106:393-397.

Kawaguchi Y, Wilson CJ, Emson PC (1990) Projection subtypes of 
rat neostriatal matrix cells revealed by intracellular injection of biocytin. J Neurosci 10:3421-3438.

Kemp JM, Powell TPS (1971) The structure of the caudate nucleus of the cat: light and electron microscopy. Philos Trans R Soc Lond [Biol] 262:383-401.

Kita H, Kitai ST (1988) Glutamate decarboxylase immunoreactive neurons in rat neostriatum: their morphological types and populations. Brain Res 447:346-352.

Kuczenski R, Segal DS (1992) Differential effects of amphetamine and dopamine uptake blockers (cocaine, nomifensine) on caudate and accumbens dialysate dopamine and 3-methoxytyramine. J Pharmacol Exp Ther 262:1085-1094.

Le Moine C, Normand E, Guitteny AF, Fouque B, Teoule R, Bloch B (1990) Dopamine receptor gene expression by enkephalin neurons in rat forebrain. Proc Natl Acad Sci USA 87:230-234.

Li SJ, Sivam SP, McGinty JF, Jiang HK, Douglass J, Calavetta L, Hong JS (1988) Regulation of the metabolism of striatal dynorphin by the dopaminergic system. J Pharmacol Exp Ther 246:403-408.

Li SJ, Jiang HK, Stachowiak MS, Hudson PM, Owyang V, Nanry K, Tilson HA, Hong JS (1990) Influence of nigrostriatal dopaminergic tone on the biosynthesis of dynorphin and enkephalin in rat striatum. Mol Brain Res 8:219-225.

Mansour A, Khachaturian H, Lewis ME, Akil H, Watson SJ (1987) Autoradiographic differentiation of mu, delta, and kappa opioid receptors in the rat forebrain and midbrain. J Neurosci 7:2445-2464.

Missale C, Castelletti L, Govoni S, Spano PF, Trabucchi M, Hanbauer I (1985) Dopamine uptake is differentially regulated in rat striatum and nucleus accumbens. $J$ Neurochem 45:51-56.

Morelli M, Carboni E, Cozzolino A, Tanda GL, Pinna A, Di Chiara G (1992) Combined microdialysis and Fos immunohistochemistry for the estimation of dopamine neurotransmission in the rat caudateputamen. J Neurochem 59:1158-1160.

Morgan JI, Curran T (1989) Stimulus-transcription coupling in neurons: role of cellular immediate-early genes. Trends Neurosci 12:459462.

Morgan JI, Curran T (1991) Proto-oncogene transcription factors and epilepsy. Trends Pharmacol Sci 12:343-349.

Mulder AH, Wardeh G, Hogenboom F, Frankhuyzen AL (1984) $\kappa$ and $\delta$-opioid receptor agonists differentially inhibit striatal dopamine and acetylcholine release. Nature 308:278-280.

Paxinos G, Watson C (1982) The rat brain in stereotaxic coordinates. New York: Academic.

Richfield EK (1991) Quantitative autoradiography of the dopamine uptake complex in rat brain using [ $\left.{ }^{3} \mathrm{H}\right] \mathrm{GBR}$ 12935: binding characteristics. Brain Res 540:1-13.

Robertson GS, Vincent SR, Fibiger HC (1990) Striatonigral projection neurons contain $\mathrm{D}_{1}$ dopamine receptor-activated c-fos. Brain Res 523: 288-290.

Robertson GS, Vincent SR, Fibiger HC (1992) $D_{1}$ and $D_{2}$ dopamine receptors differentially regulate c-fos expression in striatonigral and striatopallidal neurons. Neuroscience 49:285-296.
Sagar SM, Sharp FR, Curran T (1988) Expression of c-fos protein in brain: metabolic mapping at the cellular level. Science 240:13281331.

Schoffelmeer ANM, Rice KC, Jacobson AE, Van Gelderen JG, Hogenboom F, Heijna MH, Mulder AH (1988) $\mu$-, $\delta$ - and $\kappa$-opioid receptormediated inhibition of neurotransmitter release and adenylate cyclase activity in rat brain slices: studies with fentanyl isothiocyanate. Eur J Pharmacol 154:169-178.

Sheng M, Greenberg ME (1990) The regulation and function of c-fos and other immediate early genes in the nervous system. Neuron 4:477485.

Sivam SP (1989) Cocaine selectively increases striatonigral dynorphin levels by a dopaminergic mechanism. J Pharmacol Exp Ther 250: 818-824.

Smiley PL, Johnson M, Bush L, Gibb JW, Hanson GR (1990) Effects of cocaine on extrapyramidal and limbic dynorphin systems. J Pharmacol Exp Ther 253:938-943.

Taylor D, Ho BT (1978) Comparison of the inhibition of monoamine uptake by cocaine, methylphenidate and amphetamine. Res Commun Chem Pathol Pharmacol 21:67-75.

Tempel A, Zukin RS (1987) Neuroanatomical patterns of the $\mu, \delta$, and $\kappa$ opioid receptors of rat brain as determined by quantitative in vitro autoradiography. Proc Natl Acad Sci USA 84:4308-4312.

Vincent SR, Hökfelt T, Christensson I, Terenius L (1982) Immunohistochemical evidence for a dynorphin immunoreactive striatonigral pathway. Eur J Pharmacol 85:251-252.

Voorn P, Roest G, Groenewegen HJ (1987) Increase of enkephalin and decrease of substance $P$ immunoreactivity in the dorsal and ventral striatum of the rat after midbrain 6-hydroxydopamine lesions. Brain Res 412:391-396.

Wagner JJ, Caudle RM, Chavkin C (1992) $k$-opioids decrease excitatory transmission in the dentate gyrus of the guinea pig hippocampus. J Neurosci 12:132-141.

Werling LL, Frattali A, Portoghese PS, Takemori AE, Cox BM (1988) Kappa receptor regulation of dopamine release from striatum and cortex of rats and guinea pigs. J Pharmacol Exp Ther 246:282-286.

West RE, Miller RJ (1983) Opiates, second messengers and cell response. Br Med Bull 39:53-58.

Young ST, Porrino LJ, Iadarola MJ (1991) Cocaine induces striatal c-fos-immunoreactive proteins via dopaminergic $D_{1}$ receptors. Proc Natl Acad Sci USA 88:1291-1295.

Young WS III, Bonner TI, Brann MR (1986) Mesencephalic dopamine neurons regulate the expression of neuropeptide mRNAs in the rat forebrain. Proc Natl Acad Sci USA 83:9827-9831.

Zaborszky L, Alheid GF, Beinfeld MC, Eiden LE, Heimer L, Palkovits M (1985) Cholecystokinin innervation of the ventral striatum: a morphological and radioimmunological study. Neuroscience 14:427453. 